\title{
COMBINING THE METHODOLOGIES OF STRATEGIC ASSUMPTIONS SURFACING AND TESTING AND ORGANIZATIONAL CYBERNETICS IN MANAGING PROBLEM SITUATIONS IN ENTERPRISES
}

\author{
Dejana Zlatanovic* \\ Faculty of Economics, University of Kragujevac, Kragujevac, The Republic of Serbia
}

\begin{abstract}
The limitations of the individual use of systems methodologies in creative dealing with complex, dynamic and ambiguous problems, i.e. problem situations, caused by the increasing complexity and diversity of problem situations, indicate the necessity of a combined, i.e. synergistic use of systems methodologies. The aim of the research is to show how some limitations of the individual using of the interpretive systems methodology of Strategic Assumptions Surfacing and Testing (SAST) and Organizational Cybernetics (OC), as a functionalist systems methodology, can be eliminated by their combining. After identifying Critical Systems Thinking as a relevant conceptual framework for combining systems methodologies, the key features and limitations of SAST and OC are specified, and the assumptions, the conditions, the potential way, as well as the limitations of their combined, i.e. synergistic use are then determined. Despite the limitations, the methodologically appropriate combined use of these systems methodologies enables the improvement of managing problem situations in enterprises.
\end{abstract}

Keywords: managing problem situations in enterprises, the SAST methodology, the Organizational Cybernetics methodology, combining the SAST methodology and the Organizational Cybernetics methodology

JEL Classification: M10, M21

\section{INTRODUCTION}

Numerous problems in contemporary enterprises, according to their key characteristics - high complexity,

\footnotetext{
* Correspondence to: D. Zlatanovic, Faculty of Economics, University of Kragujevac, Dj. Pucara 3, 34000 Kragujevac, The Republic of Serbia; e- mail: dejanaz@kg.ac.rs
}

dynamics, interactivity and ambiguity - should be researched as management problem situations. Management problem situations generally represent the relevant complex, interactive, ambiguous and manageable set, i.e. systems of problems. In the conceptual framework of systems thinking, problem situations can be explored from the point of the two 
key dimensions - systems and participants. The dimension of systems expresses complexity, and the dimension of participants reflects the relationships that exist between those individuals and groups concerned with the problem situation (Jackson, 2003, 18-20, Petrović, 2010, 277-281).

Creative dealing with and managing problem situations imply using different systems methodologies for problem situations structuring. By the critical evaluation and identifications of the strengths and weaknesses of different systems methodologies, as well as by researching the usefulness of using different systemic models, methods, tools and techniques within different systems methodologies, it is found that these methodologies should be combined with each other. According to critical awareness as the relevant commitment of Critical Systems Thinking, one can conclude that all systems methodologies have some advantages and disadvantages. The fact that no methodology is able to explore all the aspects of complex problem situations in enterprises is acknowledged in this way.

The paper focuses on the combined use of the interpretive, i.e. soft systems methodology of Strategic Assumptions Surfacing and Testing (SAST) and Organizational Cybernetics as a functionalist, i.e. hard systems methodology. The basic research aim in the paper is to show how some limitations of the individual use of the above-mentioned systems methodologies can be eliminated by their combined use. Therefore, the key scientific hypothesis of the paper is that the methodologically appropriate use of SAST and OC in combination creatively improves managing problem situations in enterprises.

After the Introduction, in researching the combined use of SAST and OC, some of the relevant characteristics of Critical Systems Thinking (CST) as a conceptual framework for combining systems methodologies are identified in the paper. Taking into account critical awareness as the basic principle of CST, the key theoretical-methodological features of the researched systems methodologies are introduced. Accordingly, one specifies their key limitations in managing problem situations and determines the assumptions and conditions of their combined use.
Also, a potential way of combining SAST and OC, as well as a critical review, i.e. the benefits and limitations of the combined use of these systems methodologies in managing problem situations in enterprises are also presented. Finally, the conclusions, the standpoint on the validity of the proposed hypothesis, the main contributions and limitations of the paper as well as the directions for future research are emphasized.

\section{THE CONCEPTUAL FRAMEWORK FOR COMBINING THE SYSTEMS METHODOLOGIES}

The valid combined use of the systems methodologies, as a response to the increasing complexity and diversity of the management of problem situations, is founded within Critical Systems Thinking (CST). According to M. C. Jackson (2001, 233-234), the analysis of social paradigms and an organizational analysis (Burell \& Morgan, 1979; Morgan, 1997) are particularly important for the development of CST, since they have enabled a critique of the assumptions that different systems approaches have about social reality and organizations. In addition to this, it is important that the various human interests - technical, practical and emancipatory (Habermas, 1972, 301317) - those emphasizing the different roles of the systems methodologies and enabling a possibility of their complementary use should be identified. The attempt to reconstitute systems thinking, as a unified approach to problem solving in organizations, is suggested to be one of the CST goals. It implies showing the complementary roles that various systems methodologies can play in problem solving and decision making, as well as demonstrating the power of systems thinking, as a source of theoretical support and practical guidance in management science. Thereby, it is important to emphasize that the diversity of systems approaches is indicative of the strength, rather than the weakness of the systems movement (Jackson, 2001, 236).

CST is aimed at supporting the holistic management of the diversity of systems approaches, i.e. at revealing the ways of the appropriate combined use of diverse systems theories, methodologies, methods and models 
in order to respond to the complexity, change and diversity of problem situations in contemporary organizations (Jackson, 2010, 136). In fact, CST is a relevant stream within contemporary systems thinking, based on the following commitments: critical awareness, social awareness, dedication to human emancipation, complementarity at the level of methodology and complementarity at the theoretical level.

In the given context, the critical awareness related to the fact that all systems methodologies have certain strengths and weaknesses as well as to the researching usefulness of using different systemic models, methods, instruments and techniques within different systems methodologies is of relevant importance. Another result of critical awareness is the continual assessment of the benefits and weaknesses of all systems approaches, as well as the recognition that systems methodologies should be combined in order to address different aspects of complex problem situations.

The combined use of systems methodologies, especially the methodologies stemming from different paradigms, can be carried out in different ways. Thus, one methodology can be used as the dominant one, and another as the supportive one. Also, one methodology, or parts of one methodology, can be involved in another methodology, or one methodology can use the relevant tools of certain methodologies in combination, rather than complete methodologies etc. Table 1 shows some potential types of the combined use of systems methodologies, i.e. multi-methodology research.

Respecting the above-mentioned, and in order to identify the assumptions, conditions, ways, benefits and weaknesses of SAST and OC combining,

Table 1 Different Types of Multi-methodology Research Designs

\begin{tabular}{|c|c|c|c|}
\hline Type of Design & Method Mix & Illustration & Example \\
\hline Sequential & $\begin{array}{l}\text { Methods are employed in } \\
\text { sequence with results from one } \\
\text { methodology influencing the } \\
\text { later one. }\end{array}$ & $\begin{array}{l}\text { Statistically analyze questionnaire, then } \\
\text { follow up with some interviews to better } \\
\text { understand the results. } \\
\text { Or, undertake ethnographic research and } \\
\text { content analysis to design a questionnaire. }\end{array}$ & $\begin{array}{l}\text { (Markus, 1994) } \\
\text { (Ngwenyama \& Lee, 1997) } \\
\text { (Carlson \& Davis, 1998) }\end{array}$ \\
\hline Parallel & $\begin{array}{l}\text { Methods are carried out in } \\
\text { parallel with results mutually } \\
\text { affecting each other }\end{array}$ & $\begin{array}{l}\text { Observation and recording together with the } \\
\text { interviewing and cognitive mapping of users }\end{array}$ & $\begin{array}{l}\text { (Trauth \& O'Connor, 1991) } \\
\text { (Trauth \& Jessup, 2000) }\end{array}$ \\
\hline $\begin{array}{l}\text { Dominant } \\
\text { (Imperialist) }\end{array}$ & $\begin{array}{l}\text { One method or methodology } \\
\text { as the main approach with } \\
\text { contribution(s) from the } \\
\text { other(s) }\end{array}$ & $\begin{array}{l}\text { An intensive study using ethnography or } \\
\text { participant observation with some statistical } \\
\text { data analysis }\end{array}$ & $\begin{array}{l}\text { (Siliance \& Mouakket, } \\
\text { 1997) }\end{array}$ \\
\hline Multi methodology & $\begin{array}{l}\text { A combination of methods, } \\
\text { embodying different paradigms, } \\
\text { developed specifically for the } \\
\text { task }\end{array}$ & $\begin{array}{l}\text { Interviews, data analysis, and } \\
\text { questionnaires, combined with the root } \\
\text { definitions and conceptual models of Soft } \\
\text { Systems Methodology, and Strategic Choice }\end{array}$ & (Ormerod, 1995) \\
\hline Multilevel & $\begin{array}{l}\text { Research conducted } \\
\text { simultaneously at different } \\
\text { levels of an organization and } \\
\text { using different methods }\end{array}$ & $\begin{array}{l}\text { Survey of employees and interviews/ } \\
\text { cognitive mapping with supervisors and } \\
\text { managers }\end{array}$ & $\begin{array}{l}\text { (Taylor \& Tashakkori, } \\
\text { 1997) }\end{array}$ \\
\hline
\end{tabular}


specifying the key theoretical-methodological features of these systems approaches is of relevant importance.

THE KEY THORETICAL-

METHODOLOGICAL FEATURES OF SAST AND ORGANIZATIONAL CYBERNETICS

\section{The SAST methodology}

SAST represents a relevant interpretive systems methodology for solving unstructured, ill-defined problems, i.e. problem situations in enterprises. This methodology is suitable for pluralist problem situations, in which the focus is on the political and cultural aspects of organization. Therefore, SAST ignores the structure and functioning of an organization, i.e. problems arising from the complexity of researched areas.

Theoretically, SAST is based on the idea that problem situations should be researched from different aspects. Namely, a different, dialectical approach to objectivity is of essential importance: some dominant world view (the thesis) should be challenged by another world view, based on entirely different assumptions - the antithesis in order to bring about a conditionally more objective appreciation of a situation, expressing the elements of both the thesis and the antithesis, but going beyond them as well (Jackson, 2003, 139-140).

This approach to objectivity, as the key theoretical postulate underpinning the SAST methodology, is corresponding to the principle of participation, opposition and integration (Mason \& Mitroff, 1981, 16; Petrović, 2010, 447-448). It is about the methodology that seeks to include different levels and groups of an organization in the process of managing problem situations in enterprises, as well as other relevant stakeholders, whose perceptions and viewpoints are mutually opposed, but which should be brought into an appropriate relationship, i.e. their synthesis should be provided. Apart from the above-mentioned, the important principle of the SAST methodology is the managerial mind supporting based on the belief that managers exposed to different assumptions will enable their deeper understanding of the organization, its policies and strategies.

SAST is employed in managing problem situations throughout the following four stages (Mitroff, Emshoff \& Kilmann, 1979, 584; Jackson, 2003, 143): forming the groups, assumptions surfacing, a dialectical debate and a synthesis. Groups are formed taking into account both minimizing the differences or conflicts within the group, on the one hand, and maximizing the divergence of the perspectives between the groups, on the other (Elrod \& Moss, 1998, 284). The process of assumptions surfacing consists of the sub-processes of stakeholder analysis, the specification of assumptions and assumptions rating (Mitroff et al, 1979, 586). The most important criterion that should be respected is how stakeholders can influence the strategy and how they are affected by the strategy as well, seeking to generate the list of assumptions on which the strategy or the policy of each group is based. Although the number of assumptions is not limited, there are five assumptions that should initially be specified, so that the process is not overloaded with a large number of assumptions. Regarding the assumptions rating, the assessment of assumptions, given both the relative importance of an assumption, i.e. its importance for the success or failure of the strategy and its relative certainty, i.e. the reliability that an assumption is justifiable, are of the key importance.

As the main part of this methodology, a dialectical debate starts with the representation of the most important assumptions underpinning the strategy of each group. After that, a discussion begins and can vary depending on the following (Mason \& Mitroff, 1981, 105-106): groups can identify the same stakeholders, but different assumptions related to them; then, groups can essentially have the same stakeholders and the same set of assumptions, but they can assess the assumptions in completely different ways; also, different groups can have different stakeholders, and thereby completely different assumptions.

In order to achieve a dialectical synthesis, the modification of assumptions is essential, i.e. groups need to modify their assumptions up to the point when, if they proceed with the modification, the assumptions would not support the strategy at all. It is 
not necessary that the members of the groups change their perceptions and perspectives, but they should rather be ready to involve the opposed perspectives in the process of decision making (Van der Veen, 2003). Also, if no synthesis can be achieved, the points of disagreement need to be identified, and the ways of their elimination need to be discussed, too.

\section{Organizational Cybernetics}

As a representative of the functionalist systems paradigm, OC is focused on exploring the structure and functioning of contemporary enterprises. In fact, through the Viable System Model (VSM) as its key methodological tool, OC enables a very powerful instrumentarium of diagnosing problems in the structure and functioning of an enterprise.

The Law of Requisite Variety and the principle of recursion stand for the theoretical core of Organizational Cybernetics. The Law of Requisite Variety generally reads as follows: „Only variety can destroy variety" (Ashby, 1966, 207). It further implies the attenuation of the variety of high-variety systems and the amplification of the variety of the low-variety system. This process, called variety engineering, can be effective if organizations deal only with the part of the environment causing the threats that the organization must react to in order to survive. This is about the so-called residual variety of the environment. Analogically, it can be applied to the organization and its management, where the residual variety of the organization is relevant, i.e. the variety not absorbed by the processes of self-organization and self-regulation (Schwaninger, 2000, 211; Schwaninger, 2006, 15). The principle of recursion refers to the fact that systems are hierarchically arranged, i.e. all systems consist of a set of subsystems characterized by their own organization and regulation. At the same time, these systems are the parts of the suprasystem, i.e. the higher-order system. Each subsystem also consists of its own subsystems, and so on, all the way to the lowest levels (Beer, 1994a, 228).

Originally developed by S. Beer (Beer, 1994a; Beer 1994b; Beer 1994c), the VSM contains the following five subsystems (Brocklesby \& Cummings, 1996, 51; Howerstadt, 2010, 89; Azadeh, 2012, 67-68):

- the subsystem $S_{1}$ that represents the function of implementation, namely operational elements facing directly the external environment;

- the subsystem $S_{2}$ or the function of coordination, enabling the harmonious action of operational elements;

- the subsystem $S_{3}$ - the function of control maintaining and allocating resources to the operational elements, with the addition of the segment $\mathrm{S}_{3}{ }^{*}$, representing the channels of revision, through which the monitoring of the functioning of the operational elements is carried out;

- the subsystem $\mathrm{S}_{4}$ i.e. the function of intelligence that sees the system as a whole - its strategic opportunities, threats as well as future directions, and

- the subsystem $S_{5}$ or the function of the identity specifying the purpose of the system.

The VSM is employed in the (re)designing of the organization through the following three relevant subprocesses (Flood, 1995, 149; Petrović, 2010, 399403): the system identification, the system diagnosis and the redesign (if necessary) processes. The system identification starts with the formulation of the organizational purpose or its raison d'etre, and proceeds with specifying the following recursive levels: the system in focus, i.e. the system for achieving the purpose and the objectives resulting from the purpose - recursion level 1; the suprasystem, i.e. the relevant environment of the system in focus - recursion level 0; the operational elements of the system in focus, i.e. the subsystems of the system in focus - recursion level 2.

After identification has been carried out, in the process of the VSM use, the subprocess of diagnosing follows. It is conducted through a careful analysis of, primarily, the $S_{1}, S_{2}, S_{3^{\prime}} S_{4}$ and $S_{5}$ segments of the system in focus, only to be followed by the analysis of all information channels, transmitters and control loops. The diagnosis implies the comparison of the researched organization with the VSM and the identification of 
the problems in the structure and functioning of the organization. Accordingly, the diagnosis provides the identification of the following problems (Peréz Ríos, 2010, 1544-1547): incorrectly defined recursion levels, the inadequate identity implying that two or more different identity conceptions produce conflicts within an organization; the $S_{4}$ segment is missing or, if it does exist, it works improperly; the inadequate management style that constrains the autonomy of the $\mathrm{S}_{1}$ segment; the authoritarian $S_{2}$ segment; the dominance of the $S_{1}$ segment; the uncontrolled growth and activity of some individual parts of the organization; the communication channels in the system, as well as those existing between the system and the environment, not corresponding to information flows etc.

When some of the mentioned problems are observed in an organization, the redesigning subprocess is carried out as the final subprocess in the VSM use (Flood, 1995, 159). The first step of redesigning is the diagrammatic presentation of the identified organizational problems. Their studying and analyzing are necessary then. Hence, the formulation of some procedures is of great importance, and those are procedures for operational elements and procedures for management functions.

\section{THE ASSUMPTIONS AND CONDITIONS OF THE SYNERGISTIC USE OF THE SAST METHODOLOGY AND ORGANIZATIONAL CYBERNETICS}

Respecting the key theoretical-methodological features of the SAST methodology and OC, one can conclude that SAST is the representative of soft systems thinking, while OC is the representative of hard systems thinking. Accordingly, the following differences between hard and soft systems thinking are very important for the combined use of these two methodologies (Petrović, 2010, 46; Zexian \& Xuhui, 2010, 140-145, Zlatanović, 2010, 98).

The key difference between hard systems thinking (HST) and soft systems thinking (SST) is reflected in the interpretation of the system concept itself. The HST regards the system as an objective part of reality. On the other hand, the SST regards the system as an epistemological concept subjectively constructed by people rather than an objective entity in the real world.

In addition to this, the HST and the SST are based on different theoretical assumptions and use different analysis methods. The HST assumes that a system should have a well-defined structure and a welldefined objective. However, this kind of thinking implies optimization and cannot solve complex social problems because it ignores different perceptions, values and interests existing in organizations. On the contrary, the SST is not focused on a single welldefined problem, but rather on problem situations as the systems of problems. The focus is on improvement, rather than optimization, i.e. the focus is on the learning process.

Finally, the HST and the SST are based on the different principles of acquiring knowledge, i.e. they use different epistemological approaches. The HST regards the system intervener as an outsider of the system. Therefore, the HST corresponds with traditional epistemology employing the principle of division between the subject and the object of research. On the other hand, the SST respects the interaction between the observer, as the subject of the research, and the problem situation, as the object of the research. Accordingly, the observer is involved in the observed situation. Therefore, the SST uses the action research and interpretive paradigm in researching and improving problem situations.

In the given context, the fact that the SAST methodology, as the representative of soft systems thinking, is aimed at exploring different perceptions, beliefs, assumptions relevant stakeholders have about the problem area in the enterprise and relevant proposals for an improvement of business is of relevant importance. In contrast to this, even though Organizational Cybernetics is the representative of hard systems thinking, it is different from some other hard systems approaches, such as System Analysis, System Engineering, Traditional Operational Research, in its structural approach to systems theory. It is believed that the structural principles that are the basis of system effectiveness and their ability to survive and develop are possible to reveal. However, from the aspect of practical use, OC depends on the existence 
of the pre-defined objective as well as the individuals and the groups that agree on a specific objective. Accordingly, OC can be treated as a "methodological instrumentarium for the improvement of the design, control, the functioning of the system, aimed at achieving the pre-determined results" (Petrović, 2010, 53).

Taking into account the identified differences between the hard and the soft systems approaches, and relying on the relevant theoretical and methodological features of the SAST methodology and Organizational Cybernetics, i.e. its basic methodological instrument - the VSM - the key limitations of the given systems methodologies, relevant for their combined use, can be identified. In fact, the following limitations are of crucial importance for their combining.

Above all, the SAST methodology focuses on the relationships between the participants, i.e. on research into different perceptions, perspectives, interpretation of problem situations in enterprises. In this regard, SAST fully ignores the systems dimension, i.e. the structure and functioning of the organization. In fact, by creatively managing problem situations in enterprises, the SAST methodology effectively handles pluralism, rather than the complex nature of problem situations. On the other hand, Organizational Cybernetics focuses on the organizational structure and communication, and respects the insufficiently meaningful role of individuals in organizations. The concept of the model requires that the pre-defined goals of the organization should be followed, whereas the parts of the organization to which control is delegated are only allowed freedom in the search for the alternative ways of achieving those goals. In this way, attention is paid to the achievement of the objectives, rather than the manner in which these objectives are defined. In fact, the focus is on the systems dimension, whereas the participants dimension is ignored. Respectively, OC can effectively deal with complex problem situations, but cannot handle the pluralistic nature of problem situations.

The removal of these limitations can be achieved by their synergistic use. The conditions of the synergistic use of SAST and OC depend on the nature of the researched problem situations, i.e. on the ways objectives are defined in enterprises. In fact, if in some enterprise the objective i.e. purpose is clearly defined, from which purpose the strategy that is clearly identified stems, i.e. if there is a general agreement of the relevant stakeholders over the objectives, the policies or the strategies, then the individual employment of OC would lead to better results. In this case, the objective is clearly identified, and it is necessary that the suitable structure and functioning of the organization should be designed in order to provide the efficient realization of the identified objective.

However, if there are different interests, the perceptions and understandings of what the purpose is, i.e. what the objectives the enterprise should be following are, then the combined use of SAST and OC will generate better results. Taking into account the fact that problems in enterprises are generally characterized by complexity and pluralism, it can be concluded that the individual use of SAST or OC cannot help the adequate management of these problem situations.

Respecting the above, the combined use of SAST and OC should rely on the following key principles: participation, opposition, integration; The Law of Requisite Variety, recursion and feedback. As already mentioned, the principle of participation implies the involvement of all relevant stakeholders in the processes of problem solving and strategic decision making, i.e. in the processes of identifying and choosing appropriate organizational policies, objectives and strategies. The principle of opposition includes identifying different, opposed perceptions of the researched problem situation, i.e. opposing the views and perceptions of the policy, the objectives and the strategies that a particular enterprise should be following. By the principle of integration, identified differences seek to be overcome and allow a certain adjustment of stakeholders' viewpoints, i.e. enable a synthesis.

Respecting The Law of Requisite Variety ensures the adequate processing of the complexity of the researched problem situation, i.e. enabling the balancing of the variety of organizations, management and the relevant environment. The principle of recursion suggests the process of unfolding complexity in the 
given organization and of identifying the recursive levels. Finally, in enabling the efficient realization of objectives, the feedback control mechanism identifying deviations from the desired results and determining suitable corrective actions enhancing the creative management of problem situations in enterprises is of relevant importance.

Thus, SAST and OC can be combined in those situations in which the focus is on both the diversity of participants' views and efficiency and adaptability. Some of the application areas of combining SAST and $\mathrm{OC}$ are: the formulation and implementation of the strategy for information systems development (Clarke \& Lehaney, 2000), the identification and implementation of the approach to redesign the organizational structure (Flood, 1995), knowledge management (Pollalis \& Dimitrou, 2008) etc.

\section{A POTENTIAL WAY OF COMBINING SAST METHODOLOGY AND ORGANIZATIONAL CYBERNETICS}

In the combined use of the interpretive and functionalist systems approaches, one can observe that better results are achieved when the interpretative approach precedes the functionalist approach (Brown, Cooper \& Pidd, 2006, 667). This means that the interpretative approach should be used to make sense of the researched problem situation and help to establish a proper context within which the functionalist approach will be used. Accordingly, and taking into account the key characteristics, the advantages and the limitations of the SAST methodology and OC, the following way of the combined use of these two approaches is identified in the paper.

Including various stakeholders' opinions and perceptions, i.e. identifying various strategic assumptions, throughout the process of a dialectical debate, the SAST methodology leads to the synthesis or adjustment of conflicting assumptions. This allows the defining of the strategy that the enterprise, faced with a certain problem situation, should follow. Relying on the identified strategy, through the Viable System model, OC will enable the efficiency and adaptability of the researched enterprises. In fact, if in the subsystem $\mathrm{S}_{5}$ of the VSM, which represents the function responsible for the formulation of policies and strategies, the SAST methodology is applied, then it creates the basis for the combined use of these two approaches. In this way, some deficiencies of OC related to the inability to capture different aspects as well as the constraints of SAST concerning the structure and functioning of the company are removed.

A possible combined, i.e. synergistic use of these two approaches involves the following two key phases:

- identifying the objectives, i.e. strategies that the enterprise faced with a problem situation should follow, as well as the adequate levels of recursion, and

- designing the organizational structure and functioning that will enable the efficient achievement of the objectives, i.e. the efficient implementation of the defined strategy.

In this sense, the first phase implies the use of the SAST methodology through forming groups, assumption surfacing, a dialectical debate and a synthesis. The second phase involves the implementation of OC, i.e. the VSM, as a support to SAST in handling complexity. However, the SAST methodology, as a relevant soft systems approach, is used to provide a context within which OC, as a hard, i.e. functionalist systems approach, can be used. Given the fact that the first stage of the VSM application is the system identification, i.e. the identification of the purpose and objectives, and given the fact that the segment $S_{5}$ is actually responsible for the system identification, the combined use of these two methodologies can be represented in the conceptual framework of the VSM (Figure 1).

As one can see from Figure 1, in the segment $S_{5}$ of the VSM, the SAST methodology is first applied. When through the proper involvement of all the relevant stakeholders divided into different groups the formulation of the business strategy acceptable to the stakeholders and the one whose implementation will improve the functioning of the organization is enabled by a dialectical synthesis, then the diagnosis, i.e. determining the other relevant subsystems of the VSM, is carried out. The link between the $\mathrm{S}_{5}$ and the $\mathrm{S}_{4}$ subsystems is of relevant importance for the process of 


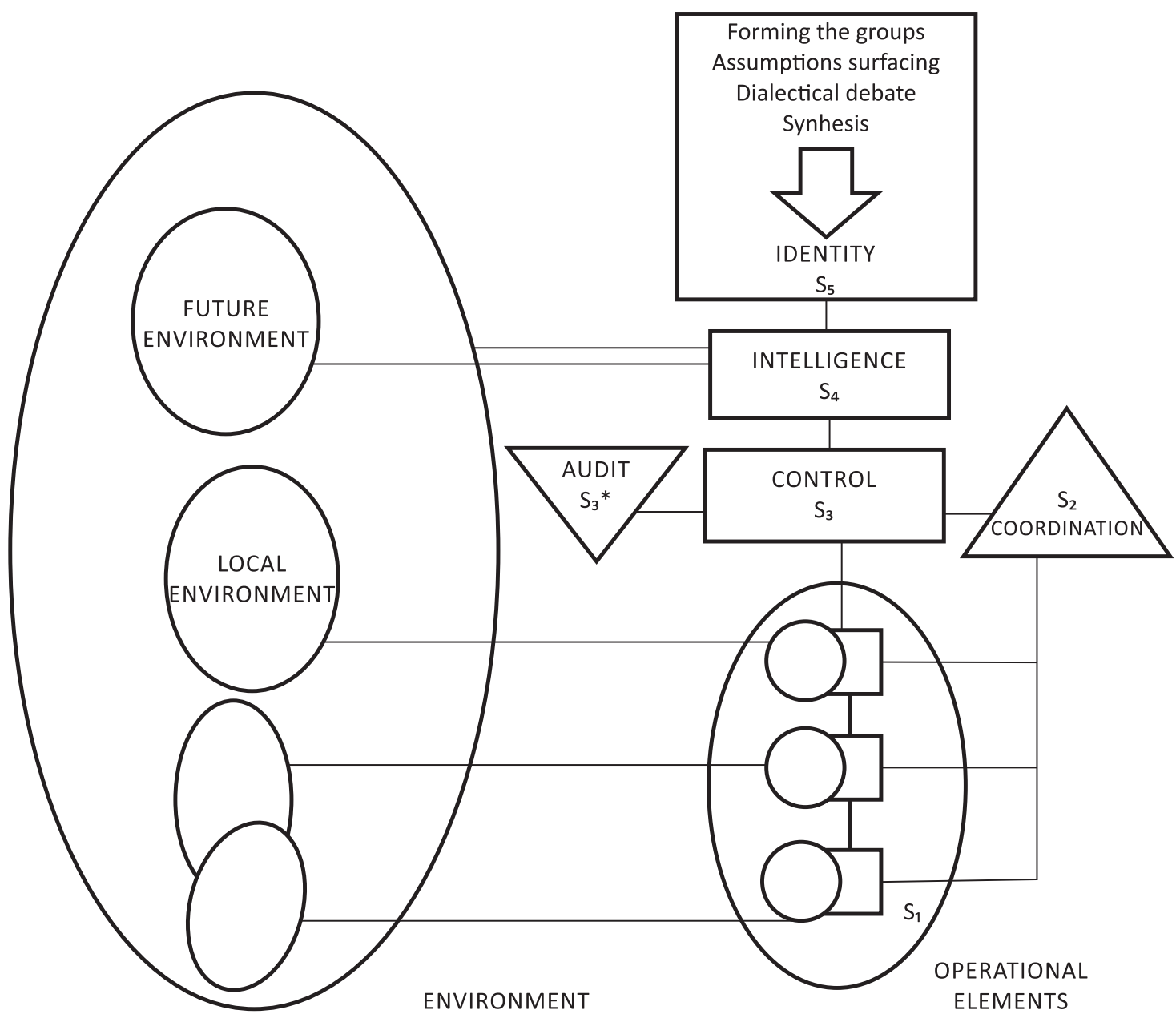

Figure 1 Combining the SAST methodology and OC in the conceptual framework of the VSM

Source: Author, adapted from Brocklesby \& Cummings, 1996, 50

the business strategy formulation due to the fact that the $\mathrm{S}_{4}$ subsystem collects relevant information about the threats and opportunities in the environment, as well as the strengths and weaknesses of the system.

When specifying the other VSM subsystems, it is, first of all, necessary that the operational elements that will enable the achievement of the identified objectives and strategies (the subsystem $S_{1}$ ), then the manner in which they need to be coordinated (the subsystem $S_{2}$ ) and controlled (the subsystem $S_{3}$ ) should be defined, and finally that different chances, threats, strengths and weaknesses of the given enterprise should be identified in implementing the defined strategy, i.e. in the realization of the defined objectives (the subsystem $\mathrm{S}_{4}$ ). When all the activities of the SAST application have been performed, then appropriate recursive levels should be identified. To effectively implement the defined objectives, the strategies and/or the policy, it is necessary that the following should be determined:

- the system in focus - the recursion level 1 (for example, the enterprise as a whole)

- the suprasystem of the system in focus - the recursion level 0 (for example, the branch of the industry in which the company operates) and 
- the operational elements of the system in focus the recursion level 2 (for example, organizational divisions or parts).

The next step in the synergistic use of the SAST methodology and $\mathrm{OC}$ is to diagnose problems in the functioning of the researched enterprises, i.e. organizations. In fact, the current situation, namely the ability of the organization to implement its previously made decisions and achieve the defined objectives/ strategies is estimated. The given organization is compared with the VSM and possible deviations are determined. In this sense, $\mathrm{S}_{1}, \mathrm{~S}_{2}, \mathrm{~S}_{3}$ and $\mathrm{S}_{4}$ are carefully examined. The diagnosis of the subsystem $\mathrm{S}_{1}$ is related to the existing operational elements of the system in focus, i.e. to the appropriate organizational units responsible for the achievement of the identified objectives/strategies. In this sense, it is estimated whether the specified organizational units are viable systems themselves. This is carried out by identifying their local management, environment, autonomy, and the corresponding limitations. In this way, a conclusion can be drawn with respect to the extent to which the operational elements absorb the complexity the given organization is being faced with.

The diagnosis of the subsystem $S_{2}$ implies identifying the mutual links between the organizational units within the enterprise, i.e. the way the functioning of the operational elements is coordinated. It is important to determine whether this segment really exists in the given organization according to the concept of the VSM as well as whether there are proper procedures and coordination teams, and to determine how authority is applied, what the sources of disturbances and conflicts are etc. The function of control, i.e. the subsystem $\mathrm{S}_{3^{\prime}}$ is diagnosed through: the identification of those carrying out control in the enterprise, the determination of the way the resources are allocated, the specifying of the level of autonomy, i.e. the freedom that the operational elements have, as well as determining whether this function is centralized or decentralized, bureaucratic or non-bureaucratic etc. Specifying the opportunities, threats, strengths and weaknesses of the researched enterprise is the basis for the diagnosis of the $\mathrm{S}_{4}$ segment. Also, it is necessary to determine whether such a segment really exists in the enterprise, whether and how the collected pieces of information about the strengths, weaknesses, opportunities and threats are submitted to decision makers etc.

Since the combined use of SAST and OC involves the application of SAST in the $\mathrm{S}_{5}$ segment, thus eliminating possible limitations related to the (non)involvement of all relevant stakeholders in the decision-making processes or those related to the inadequately formulated policy or strategy, the diagnosis of this segment was partially implemented in the first stage of combining SAST and OC. However, the diagnosis of this function can further be implemented in terms of determining the real involvement of the stakeholders in the policies and strategies formulation process, i.e. the assessments whether all relevant stakeholders are included in the process, whether the defined organizational culture supports the implementation of the defined policy, objectives and strategies, as well as the commitment of the stakeholders in the implementation of the chosen strategy.

The issues in functioning, revealed by the previously described process of diagnosis, need to be grouped, and a possible redesign of the organization should be made a proposal for, so that it could operate in accordance with the relevant cybernetic principles and laws. As in the case of an individual use of $\mathrm{OC}$, the procedures of the operational elements and the procedures of the management functions are important.

\section{AN EXAMPLE OF THE INTEGRATED APPLICATION OF THE SAST METHODOLOGY AND ORGANIZATIONAL CYBERNETICS IN THE ENTERPRISE}

The way of combining SAST and OC described above can be illustrated by the following example of using the above approaches in the strategies formulation and implementation process in the chosen enterprise $A$, which sells vehicle spare parts (Zlatanović, 2015, 250289).

First of all, in the context of a possible use of the SAST methodology in the enterprise, an interview with the top management was conducted in order to provide 
information about what the problems the enterprise is facing due to the global economic crisis are. In this way, it was found that the economic crisis negatively affected the operations of the given enterprise, i.e. the enterprise was faced with the following problems: a loss of purchasing power, the financial problems of some customers (for example, a blocked account and the inability to settle obligations), a lack of new liquid customers, as well as the inability to renew the vehicle park. As a result, there is a decrease in the sales and a decrease in profitability. Thus, the first symptoms of the crisis were observed in the enterprise, but its survival is not threatened. In the given situation, the enterprise's management decided to expand its business and enter new business operations. With such a determined strategy, there was a disagreement primarily between the internal stakeholders. Namely, there were conflicting perceptions of the owners, the top management, and the other employees of the enterprise (for example, the top management and the middle management).

The described problem situation represents an ambiguous, i.e. pluralist problem situation, in which the SAST methodology can be applied. The interview with the top management of the researched enterprise, in addition to the information relevant for the formulation of the problem and the proposed solutions to the problem, enabled the identification of the key assumptions supportive of the proposed strategy for entering new business, as well as an alternative strategy. For example, one of the key assumptions on which the top management based the strategy for entering new businesses is that this would reduce the risk. Also, the management started from the assumption that this would increase demand for their commodities, which would lead to better business results and the like. An appropriate questionnaire was created, based on the collected data and respecting the key determination of the SAST methodology. In addition, the top management of the enterprise $\mathrm{A}$ provided the information about which enterprises are its relevant stakeholders, i.e. which enterprises are the most important customers, suppliers and competitors.

The questionnaire was first distributed to the employees of the enterprise A as its internal stakeholders, and then to the representatives of its external stakeholders, such as the representatives of the suppliers, i.e. the manufacturers, the representatives of the customers, the competitors, the financial institutions and the local authorities. The aim was to establish to which extent the respondents agreed with the determined strategy for entering new business and the assumptions supporting it, and/or the alternative strategy and the assumptions supporting it.

The empirical results obtained by using the appropriate statistical methods, such as the methods of the descriptive statistical analysis, testing the statistically significant differences between the means and the Hi square $\left(\chi^{2}\right)$ test, represent the basis for forming the groups and identifying the assumptions, as the initial stages of the application of the SAST methodology. Taking into account that different types of stakeholders are crucial for the given context, the link between the different types of the stakeholders and their (dis)agreement with the proposed strategy for entering new business may be established, and for this purpose, the results of the Hi square $\left(\chi^{2}\right)$ test can be used (Table 2). In this way, certain groups of the respondents can be distinguished according to the degree of the agreement with the determined strategy for entering new business (for example, the group For, the group Against and the group For and Against are singled out).

In the process of the stakeholder analysis, the results of testing the significance of the differences also indicate some statistically significant differences between the respondents depending on the level of education, the type of stakeholders etc. The results of descriptive statistics indicate the degree of the respondents' agreement with the defined assumptions, as well as the level of the importance and certainty of the assumptions. For example, the results of descriptive statistics showed that the majority of the respondents agreed with the assumption that the growth of demand leads to better business results $(\mathrm{M}=4.45)$, whereas the respondents least agree with the assumption that entering new business reduces the risk $(\mathrm{M}=3.38)$. Consequently, it can be concluded that one of the initial assumptions of the top management of the researched enterprise (the one saying that entering new business reduces the risk) is challenged, i.e. that the relevant stakeholders have different opinions. 
Table 2 The results of the Hi square $\left(\chi^{2}\right)$ test

\begin{tabular}{|c|c|c|c|c|c|}
\hline \multirow{2}{*}{ Stakeholders } & & \multicolumn{3}{|c|}{ (Dis)agreement with the proposed strategy } & \multirow{2}{*}{ Total } \\
\hline & & Group1 & Group 2 & Group 3 & \\
\hline \multirow{2}{*}{ Enterprise A } & Total & 16 & 4 & 0 & 20 \\
\hline & $\%$ & $80,0 \%$ & $20,0 \%$ & $0,0 \%$ & $100,0 \%$ \\
\hline \multirow{2}{*}{$\begin{array}{l}\text { Representatives of the financial } \\
\text { institutions }\end{array}$} & Total & 0 & 0 & 4 & 4 \\
\hline & $\%$ & $0,0 \%$ & $0,0 \%$ & $100,0 \%$ & $100,0 \%$ \\
\hline \multirow{2}{*}{$\begin{array}{l}\text { Representatives of the } \\
\text { manufacturers }\end{array}$} & Total & 14 & 1 & 12 & 27 \\
\hline & $\%$ & $51,9 \%$ & $3,7 \%$ & $44,4 \%$ & $100,0 \%$ \\
\hline \multirow{2}{*}{ Representatives of the competition } & Total & 8 & 2 & 0 & 10 \\
\hline & $\%$ & $80,0 \%$ & $20,0 \%$ & $0,0 \%$ & $100,0 \%$ \\
\hline \multirow{2}{*}{ Representatives of the customers } & Total & 8 & 3 & 2 & 13 \\
\hline & $\%$ & $61,5 \%$ & $23,1 \%$ & $15,4 \%$ & $100,0 \%$ \\
\hline \multirow{2}{*}{$\begin{array}{l}\text { Representatives of the local } \\
\text { authorities }\end{array}$} & Total & 1 & 2 & 0 & 3 \\
\hline & & $33,3 \%$ & $66,7 \%$ & $0,0 \%$ & $100,0 \%$ \\
\hline \multirow{2}{*}{ Total } & Total & 47 & 12 & 18 & 77 \\
\hline & $\%$ & $61,0 \%$ & $15,6 \%$ & $23,4 \%$ & $100,0 \%$ \\
\hline
\end{tabular}

$\chi^{2}=37,13, p=0,000$; Group 1 - Group For entering new business; Group 2 - Group Against; Group 3 - Group For and Against

Source: Author

The alternative assumption with the highest mean is that entering new business involves the additional training of the employees $(\mathrm{M}=4.23)$. In contrast to this, the alternative assumption with the lowest level of the respondents' agreement is that the costs of entering new business are higher than the expected revenues $(\mathrm{M}=3.33)$. Therefore, the respondents regard the additional training of the employees as one of the key assumptions underpinning the alternative strategy. It can be assumed that this standpoint reflects resistance to change, but it can also be the consequence of the fact that the additional training of the employees requires additional financial recourses.

The identified differences are the basis for the phases of the debate and the synthesis, in which all the relevant stakeholders should be involved, with the researcher as a potential moderator. Due to the inability of the researcher to carry out these phases in real terms, the conclusions derived from a potential debate and synthesis were presented, respecting the given research results. The debate over the conflicting assumptions can be developed in different ways. For example, the assumption that entering new business will meet the different needs of customers and consumers and that this will lead to increased demand is based on the specific market information and the trends existing in the given field of business. The explanation of the given assumptions is reflected in the fact that the variety and the quality are more important to customers and consumers than the price is. Such reasoning and the assumption are supported by the long-term experience of the enterprise's management and the current trends in the given business area. This assumption can be rebutted by the fact that the market research did not equally include all the categories of customers. Since some categories of customers value the price more, it can challenge the prior explanation. Also, the experience of the management and the current trends are insufficient, because different social and structural changes require continuous monitoring and market research. The other assumptions may be criticized in a similar manner.

Nevertheless, despite the conflicting assumptions, and taking into account that the given research indicated 
the existence of the group supporting both the strategy for entering new business and the alternative one (Group For and Against), one can conclude that a synthesis between the initially conflicting assumptions can be achieved, which in turn means that the strategy for entering new business, together with some aspects of the alternative strategy, can be applied to the selected enterprise A.

According to the above-mentioned, OC can be applied as a support to the SAST methodology in implementing the defined strategies. Respectively, the enterprise can be explored in the conceptual framework of the VSM, which would identify the problems in the structure and functioning of the enterprise. In this regard, in the process of the system identification, as the system in focus, i.e. as the operational elements by which the enterprise strives to realize its mission, and which refers to the provision of the high-quality system of services related to the sale and maintenance of various categories of vehicles, the sector of parts selling and the sector of vehicle sale and repair, which can be further decomposed by different types of products (the subsystems of the system in focus), were singled out. By means of direct and feedback links, the enterprise is also connected with the automotive industry, which represents a system of a higher order, i.e. the relevant environment of the enterprise.

This refers to the enterprise characterized by the functional organizational structure, and the following problems have been identified in comparing it with the VSM: the inadequate coordination between the specified operational elements, centralized control, the insufficient development of the audit channels, the disintegrated function of intelligence, an inadequate corporate culture, a lack of the stakeholder involvement in the process of formulating objectives and policies etc.

In accordance with the identified problems, it can be concluded that the redesign of the researched enterprise implies respecting the cybernetic principles and laws in order to implement the defined purpose and strategy. This further involves the improvement of each one of the subsystems of the VSM, i.e. the functions of implementation, coordination, control, intelligence and identity, as well as the improvement of the information flows and the communication channels. Overall, the redesign of the researched enterprise means that the operational elements must be viable systems by themselves with all meta-systems functions.

Thus, the identification of the recursion levels, the diagnosis of the VSM functions and a possible redesign of the given enterprise shows the way how the defined strategy for entering new business can effectively be implemented by using suitable cybernetic instruments. In this way, communication and control can be improved, as well as the adaptability of the researched enterprise.

In addition, the information obtained by the possible application of the VSM can be included in the strategy formulation process. Specifically, apart from a possible combined application of the SAST methodology and OC, in which SAST is the dominant methodology, and $\mathrm{OC}$ is the supportive one, the exploration of the combined use of SAST and OC, where OC is the dominant methodology and the SAST methodology is the supportive one, is of relevant importance. In fact, the problems diagnosed by using the VSM can be the basis for formulating appropriate business strategies, as a response to the identified problems.

\section{CRITICAL REVIEW}

Conducting research in different perceptions, interests, value systems and goals of relevant stakeholders by applying the SAST methodology ensures effective dealing with the pluralistic aspects of the researched problem situation, i.e. the participants dimension. In contrast, through the VSM, OC contributes to the creation of an efficient and adaptable organization that will implement the previously agreed upon objectives and strategies of relevant stakeholders, i.e. addressing the system dimension more efficiently. In this way, the identified key weaknesses of the SAST methodology and OC will be overcome. Also, the following limitation of SAST will be removed by combining SAST and OC: SAST is focused on the process of problem solving and decision making, rather than on the implementation of the preliminarily identified 
alternatives and solutions resulting from the process of dialectical synthesis. In fact, it is OC that will provide the creation of an organizational structure by which the pre-defined solutions will be implemented. Then, the critiques of the VSM referring to the fact that the VSM only allows a search for the alternative ways of achieving the defined objectives can be eliminated by its combined use with the SAST methodology.

However, some weaknesses of the SAST methodology and OC will not be removed by combining them with each other. These are the following limitations of the primary SAST methodology that will not be eliminated by using OC as the supportive methodology: in many situations, the causes and stimuli for the implementation of the dialectical process of problem solving, i.e. problem situation structuring, as well as the sources of alternative, conflicting solutions to problems cannot be clearly identified; there are no clear guidelines on how to come to a synthesis, and it is not certain, either, whether the entire process will result in a synthesis.

Also, there are some common limitations characterizing SAST and OC, related to the fact that neither SAST nor OC will produce good results in coercive problem situations. Namely, critics point out the fact that the implementation of the respective approaches will primarily be in the interest of those who have power since none of these methodologies are concerned with the issues of power, the ways it is distributed throughout an organization and the like. Consequently, it is very difficult to provide the genuine, authentic participation of all relevant stakeholders, and some questions are never asked and will not be examined. In fact, the issue of the real involvement of stakeholders and their commitment to the implementation of the formulated strategy will not be adequately treated with the combined use of SAST and OC. In this way, that neither the SAST methodology though identifying hidden assumptions nor OCwill help handle the different power relations that exist in an enterprise is confirmed.

In addition to the foregoing, there are also some philosophical, cognitive, cultural and practical limitations relevant for the combined use of the SAST methodology and OC (Mingers \& Brocklesby, 1997;
Mingers, 2001; Kotiadis \& Mingers, 2006). Since it is a combination of the methodologies stemming from different paradigms, the especially important problem is the paradigm incommensurability, for which the following fact is the crucial one: „A group of scientists relying on a different paradigm sees different things when they look from the same point in the same direction" (Kuhn, 1962, according to Petrovic, 2004, 164). Then, a lack of competence in using both approaches represents an important cultural barrier. Different types of personalities will have different tendencies to use some approaches, and there will be some difficulties in shifting the paradigm, which presents the cognitive barriers to the combining of the given approaches. Finally, the following practical limitations may be emphasized: the combined use of SAST and OC requires more time; the characteristics of the observed problems indicate the greater effectiveness of the individual use of these methodologies; a lack of experience; a tendency to conservatism and the like.

\section{CONCLUSION}

Taking into account the identified constraints of the SAST methodology and OC, the possible way of the integrated use of these systems approaches, which includes the complete implementation of the SAST methodology in the subsystem $\mathrm{S}_{5}$ of the VSM that defines the organizational identity is presented and illustrated in this paper. Since the system identification, i.e. the identification of the objectives to be pursued enables the identification of the different perceptions of relevant stakeholders by using the SAST methodology in the subsystem $S_{5^{\prime}}$ a further diagnosis of the enterprise, i.e. the organization in the conceptual framework of the VSM enables the identification of problems in the structure and function of the organization. It can be concluded that the synergistic use of the SAST methodology and OC eliminates some limitations of their individual use. Nevertheless, some deficiencies (such as managing coercive problem situations, as well as philosophical, cultural, cognitive and practical constraints) cannot be eliminated.

Despite these limitations, some possibilities and strengths of combining these systems methodologies 
in managing problem situations in enterprises have been shown in this paper. In fact, the contribution of the presented research is reflected in the study of the important issues in contemporary systems science related to combining the systems methodologies from different paradigms. The identification of the methodologically appropriate combining of SAST and $\mathrm{OC}$ that can creatively improve the process of managing problem situations in enterprises may be emphasized as a genuine contribution.

In fact, the conducted research first enables the identification of the problem situations in the enterprises where better results are achieved by combining the SAST methodology and OC, rather than by having them individually used. In the methodological sense, the implications of the conducted research concern the precise sequence of the application of the appropriate tools, i.e. the methods of these methodologies in managing problem situations in enterprises. The practical implications of the presented research are reflected in highlighting the ways of how the instruments of the given systems methodologies can help managers holistically understand and improve the problem situations management process in modern enterprises. Therefore, the overall considerations as well as the above-mentioned research contributions lead to the conclusion that the key hypothesis in the paper is confirmed.

However, we should point out the following limitations of the research. First of all, in this paper, one of the possible ways of combining the SAST methodology and OC, in which the application of the SAST methodology has preceded the application of OC, is considered. Consequently, the combined use of the SAST methodology and OC, in which OC is dominant, and SAST is the supportive methodology, presents a relevant area for future research. In addition to this, allow us to emphasize the limitation related to the fact that the possibilities of combining SAST and OC with some emancipatory systems approaches, such as Critical Systems Heuristics and Team Syntegrity, are not researched in the paper. Thus, in the context of such constraints, their synergistic use with an emancipatory systems methodology in order to adequately research the issues related to the power relations and coercion in modern enterprises is of particular importance for future research.

\section{REFERENCES}

Ashby, W. R. (1966). An Introduction to Cybernetics. New York, NY: John Wiley and Sons, Inc.

Azadeh, A., Darivandi, K., \& Fathi, E. (2012). Diagnosing, Simulating and Improving Business Process Using Cybernetic Laws and the Viable System Model: The Case of a Purchasing Process. Systems Research and Behavioral Science, 29(1), 66-86. doi: 10.1002/sres.1102

Beer, S. (1994a). Brain of the Firm. Chichester, UK: John Wiley and Sons.

Beer, S. (1994b). Diagnosing the System for Organization. Chichester, UK: John Wiley and Sons.

Beer, S. (1994c). The Heart of Enterprise. Chichester, US: John Wiley and Sons.

Brocklesby, J., \& Cummings, S. (1996). Designing a Viable Organization Structure. Long Range Planing, 29(1), 49-57. doi:10.1016/0024-6301(95)00065-8

Brown, J., Cooper, C., \& Pidd, M. (2006). A taxing problem: The complementary use of hard and soft OR in the public sector. European Journal of Operational Research, 172(2), 666679. doi:10.1016/j.ejor.2004.10.016

Burell, G., \& Morgan, G. (1979). Sociological Paradigms and Organizational Analysis. London, UK: Heinemann.

Carlson, P., \& Davis, G. (1998). An investigation of media selection among directors and managers: From "self" to "other" orientation. MIS Quarterly, 22(3) 335-362. doi: $10.2307 / 249669$

Clarke, S., \& Lehaney, B. (2000). Mixing Methodologies for Information Systems Development and Strategy: A Higher Education Case Study. The Journal of the Operational Research Society, 51(5), 542-556. doi:10.1057/palgrave.jors. 2600865

Elrod, R., \& Moss, S. (1998). Adversarial Decision Making: Benefits or Losses. Omega-International Journal for Managemet Science, 22(3), 283-289. doi:10.1016/0305-0483(94)90041-8

Flood, R. L. (1995). Solving Problem Solving - A Potent Force for Effective Management. Chichester, UK: John Wiley and Sons.

Habermas, J. (1972). Knowledge and Human Interests. London, UK: Heinemann. 
Howerstadt, P. (2010). The Viable System Model. In M. Reynolds, \& S. Holwell (Eds.). Systems Approaches to Managing Change: A Practical Guide (pp. 191-242). London, UK: Springer.

Jackson, M. C. (1994). Critical Systems Thinking: Beyond the Fragments. System Dynamics Review, 10(2/3), 213-229. doi: 10.1002/sdr.4260100209

Jackson, M. C. (2001). Critical Systems Thinking and Practice. European Journal of Operational Research, 128(2), 233-244. doi:10.1016/S0377-2217(00)00067-9

Jackson, M. C. (2003). Systems Thinking: Creative Holism for Managers. New York, NY: John Wiley and Sons.

Jackson, M. C. (2010). Reflections on the development and contribution of critical systems thinking and practice. Systems Research and Behavioral Science, 27(2), 133-139. doi: 10.1002/sres.1020

Kotiadis, K., \& Mingers, J. (2006). Combining PSMs with Hard OR Methods: The Philosophical and Practical Challenges. The Journal of the Operational Research Society, 57(7), 856-867. doi:10.1057/palgrave.jors.2602147

Kuhn, T. (1962). The Structure of Scientific Revolutions. The 2nd Edition. Chicago, US: The University of Chicago Press.

Markus, L. (1994). Electronic mail as the medium of managerial choice. Organization Science, 5(4), 502-527. doi: 10.1287/ orsc.5.4.502

Mason, R., \& Mitroff, I. (1981). Challenging strategic planning assumptions. New York, NY: John Wiley and Sons.

Mingers, J. (1997). Multiparadigm multimethodology. In J. Mingers, \& A. Gill (Eds.). Multimethodology: The Theory and Practice of Combining Management Science Methodologies (pp. 1-20). Chichester, UK: John Wiley \& Sons.

Mingers, J. (2001). Combining IS Research Methods: Towards a Pluralist Methodology. Information Systems Research, 12(3), 240-259.

Mingers, J., \& Broclesby, J. (1997). Multimethodology: towards a framework for mixing methodologies. Omega - International Journal for Management Science, 25(5), 489-509. doi:10.1016/ S0305-0483(97)00018-2

Mitroff, I. I., Emshoff, J. R., \& Kilmann, R. H. (1979). Assumptional analysis: a methodology for strategic problem solving. Management Science, 25(6), 583-593. doi: 10.1287/ mnsc. 24.1 .44

Morgan, G. (1997). Images of Organization. London, UK: SAGE Publications.
Ngwenyama, O., \& Lee, A. (1997). Communication richness in electronic mail: Critical social theory and the contextuality of meaning. Management Information Systems Quarterly, 21(2), 145-167. doi: 10.2307/249417

Ormerod, R. (1995). Putting Soft OR Methods to Work: Information Systems Strategy Development at Sainsbury's. The Journal of the Operational Research Society, 46(3), 277-293. doi: $10.2307 / 2584322$

Pérez Ríos, J. (2010). Models of organizational cybernetics for diagnosis and design. Kybernetes, 39(9/10), 1529-1550. doi: $10.1108 / 03684921011081150$

Petrović, S. P. (2004). Sistemski prilazi rešavanju praktičnih upravljačkih problema. Ekonomski anali, 160, 147-177.

Petrović, S. P. (2010). Sistemsko mišljenje, Sistemske metodologije. Kragujevac, Republika Srbija: Ekonomski fakultet Univerziteta u Kragujevcu.

Pollalisa, Y. A., \& Dimitriou, N. K. (2008). Knowledge Management in Virtual Enterprises: A Systemic Multimethodology Towards the Strategic Use of Information. International Journal of Information Management, 28(4), 305-321. doi:10.1016/j.ijinfomgt.2008.02.005

Schwaninger, M. (2000). Managing Complexity - The Path Toward Intelligent Organization. Systemic Practice and Action Research, 13(2), 207-241. doi: 10.1023/A:1009546721353

Schwaninger, M. (2006). Intelligent Organizations - Powerful Models for Systemic Management. Berlin, Germany: Springer.

Sillince, J., \& Mouakket, S. (1997). Varieties of political process during systems development. Information Systems Research, 8(4), 368-397. doi: 10.1287/isre.8.4.368

Taylor, D., \& Tashakkori, A. (1997). Towards an understanding of teachers' desire for participation in decision making. Journal of School Leadership, 7(1), 1-20.

Trauth, E., \& O'Connor, B. (1991). A study of the interaction between information technology and society: An illustration of combined qualitative research methods. In H. E. Nissen, H. Klein, \& R. Hirscheim (Eds.). Information Systems Research: Contemporary Approaches and Emergent Traditions (131-143). North Holland, Amsterdam.

Trauth, E., \& Jessup, L. (2000). Understanding computermediated discussions: Positivist and interpretive analyses of group support system use. Management Information Systems Quarterly, 24(1), 43-79. doi: 10.2307/325097

Van der Veen, C. (2003, November). Deciding on Wicked Strategy Problem. Paper presented at the 23th SMS Annual International Conference, Baltimore, US. 
Zexian, Y., \& Xuhui, Y. (2010). A Revolution in the Field of Systems Thinking - A Review of Checkland's Systems Thinking. Systems Research and Behavioral Science, 27(2), 140155. doi: 10.1002/sres.1021

Zlatanović, D. (2010). Strukturiranje upravljačkih problemskih situacija Metodologijom soft sistema. Ekonomski horizonti,
12(2), 95-112.

Zlatanović, D. (2015). Metodološki aspekti kombinovanog korišćenja sistemskih metodologija u upravljanju problemskim situacijama poslowne ekonomije. Neobjavljena doktorska disertacija, Kragujevac, Republika Srbija: Ekonomski fakultet Univerziteta u Kragujevcu.

\section{Received on $10^{\text {th }}$ March 2016, after two revisions, accepted for publication on $14^{\text {th }}$ April 2016. Published online on $25^{\text {th }}$ April 2016.}

Dejana Zlatanovic is an Assistant Professor, teaching the subjects of Economic Cybernetics, Management Science, and Critical Managing Problem Situations, at the Faculty of Economics, University of Kragujevac, Kragujevac, the Republic of Serbia, where she received her PhD degree. Her research interest is focused on the cybernetic approach to dealing with complex problems in enterprises, the holistic conceptualizing and creative managing of problem situations, systems methodologies for problem situations structuring. 


\title{
KOMBINOVANJE METODOLOGIJA IDENTIFIKOVANJA I TESTIRANJA STRATEGIJSKIH PRETPOSTAVKI I ORGANIZACIONE KIBERNETIKE U UPRAVLJANJU PROBLEMSKIM SITUACIJAMA U PREDUZEĆIMA
}

\author{
Dejana Zlatanović* \\ Ekonomski fakultet Univerziteta u Kragujevcu
}

\begin{abstract}
Manjkavosti individualne primene sistemskih metodologija u kreativnom bavljenju složenim, izmenljivim i višeznačnim upravljačkim problemima, tj. problemskim situacijama, uslovljene rastućom kompleksnošću i raznovrsnošću problemskih situacija, ukazuju na neophodnost kombinovane upotrebe sistemskih metodologija. Cilj istraživanja u radu je pokazati da se određena ograničenja individualne upotrebe interpretativne sistemske metodologije Identifikovanja i testiranja strategijskih pretpostavki (ITSPmetodologija) i funkcionalističke metodologije Organizacione kibernetike (OK) u upravljanju problemskim situacijama u preduzećima mogu otkloniti njihovim kombinovanjem. Nakon identifikovanja kritičkog sistemskog mišljenja, kao odgovarajućeg koncepcijskog okvira kombinovanja sistemskih metodologija, u radu su precizirana ključna svojstva i ograničenja ITSP-metodologije i metodologije OK, a zatim su opredeljene pretpostavke, uslovi, način i ograničenja njihovog sinergijskg korišćenja. Uprkos ograničenjima, metodološki primereno sinergijsko korišćenje odnosnih sistemskih metodologija omogućava unapređenje procesa upravljanja problemskim situacijama u preduzećima.
\end{abstract}

Ključne reči: upravljanje problemskim sitaucijama u preduzećima, metodologija Identifikovanja i testiranja strategijskih pretpostavki, metodologija Organizacione kibernetike, kombinovanje ITSP metodologije i OK metodologije

JEL Classification: M10, M21

\section{UVOD}

Brojne probleme u savremenim preduzećima, shodno njihovim ključnim određenjima - visoka kompleksnost, dinamičnost, interaktivnost i višeznačnost - treba

\footnotetext{
* Korespondencija: D. Zlatanović, Ekonomski fakultet Univerziteta u Kragujevcu, Đ. Pucara 3, 34000 Kragujevac, Republika Srbija; e-mail: dejanaz@kg.ac.rs
}

istraživati kao upravljačke problemske situacije. Upravljačke problemske situacije, generalno, predstavljaju odgovarajuće kompleksne, interaktivne, dinamične, višeznačne i upravljive skupove, tj. sisteme problema. U koncepcijskom okviru sistemskog mišljenja, problemske situacije mogu biti istražene sa stanovišta dve ključne dimenzije - dimenzije sistema i dimenzije odnosa učesnika. Dimenzija sistema istražuje složenost, a dimenzija učesnika, 
odnose između pojedinaca i grupa tangiranih nekom problemskom situacijom (Jackson, 2003, 18-20, Petrović, 2010, 277-281).

Kreativno bavljenje upravljačkim problemskim situacijama implicira korišćenje različitih sistemskih metodologija. Kritičkim preispitivanjem teorijskih pretpostavki sistemskih metodologija, identifikovanjem njihovih snaga i slabosti, kao i istraživanjem korisnosti upotrebe različitih sistemskih modela, metoda, tehnika i instrumenata u okviru različitih sistemskih metodologija, dolazi se do saznanja da bi sistemske metodologije trebalo kombinovano koristiti. Naime, polazeći od tzv. kritičke svesnosti, kao relevantnog principa, tj. obaveze kritičkog sistemskog mišljenja, može se zaključiti da svaka sistemska metodologija poseduje određene prednosti i nedostatke. Time se priznaje činjenica da su problemi u savremenim preduzećima, po pravilu, toliko kompleksni da individualna primena određene metodologije ne može da pomogne $u$ bavljenju svim njihovim aspektima.

Predmet istraživanja $u$ radu je sinergijsko korišćenje interpretativne, tj. soft sistemske metodologije Identifikovanja i testiranja strategijskih pretpostavki (ITSP-metodologije) i Organizacione kibernetike (OK), kao funkcionalističke, tj. hard sistemske metodologije $\mathrm{u}$ strukturiranju upravljačkih problemskih situacija u preduzećima.

Osnovni cilj rada je pokazati da manjkavosti individualne upotrebe navedenih sistemskih metodologija mogu biti otklonjene njihovim sinergijskim, odnosno, kombinovanim korišćenjem.

Shodno opredeljenom predmetu i cilju istraživanja, osnovna naučna hipoteza rada je da se metodološki primerenim kombinovanjem ITSP-metodologije i metodologije OK kreativno može unaprediti proces upravljanja problemskim situacijama u preduzećima.

$\mathrm{U}$ istraživanju kombinovane upotrebe ITSPmetodologije i OK, u radu su, nakon uvoda, identifikovana neka od relevantnih svojstava kritičkog sistemskog mišljenja, kao koncepcijskog okvira kombinovanja sistemskih metodologija. Respektujući kritičku svesnost predstavljena su ključna teorijskometodološka određenja datih sistemskih metodologija. $\mathrm{Na}$ osnovu toga, precizirana su njihova osnovna ograničenja u upravljanju problemskim situacijama u preduzećima i opredeljene odgovarajuće pretpostavke i uslovi njihovog sinergijskog korišćenja. Takođe, prikazan je mogući način kombinovanja ITSP-a i OK i predstavljen kritički osvrt, tj. dometi i ograničenja u upravljanju problemskim situacijama u preduzećima. Konačno, izvedeni su odgovarajući zaključci i opredeljen stav o osnovnoj hipotezi rada, istaknuti doprinosi i ograničenja rada, i identifikovani mogući pravci budućih istraživanja.

\section{KONCEPCIJSKI OKVIR KOMBINOVANJA SISTEMSKIH METODOLOGIJA}

Validno kombinovanje sistemskih metodologija, kao odgovor na rastuću kompleksnost i raznovrsnost upravljačkih problemskih situacija u organizacijama, utemeljeno je u okviru kritičkog sistemskog mišljenja (KSM). Prema M. C. Jackson-u (2001, 233234), za razvoj KSM-a su posebno važne analiza društvenih paradigmi i organizaciona analiza (Burell \& Morgan, 1979; Morgan, 1997), budući da su omogućile kritiku pretpostavki koje različiti sistemski prilazi imaju o društvenoj realnosti i organizacijama. Osim navedenog, od odgovaraućeg značaja je i identifikovanje različitih ljudskih interesa - tehnički, praktični i emancipatorni (Habermas, 1972, 301-317), uz pomoć kojih se ističu različite uloge sistemskih metodologija i stvara mogućnost njihove komplementarne upotrebe. Kao jedan od ciljeva razvoja KSM-a, može se navesti pokušaj da se sistemsko mišljenje rekonstituiše kao unificirani prilaz za rešavanje problema $u$ organizacijama. Navedeno podrazumeva ukazivanje na komplementarnost uloga koje različite sistemske metodologije mogu da imaju u rešavanju problema i odlučivanju, ali i pokazivanje moći sistemskog mišljenja, kao izvora teorijske podrške i praktičnih smernica u Management Science-u. Pri tome je važno naglasiti da raznovrsnost sistemskih prilaza predstavlja iskaz snage sistemskog pokreta, a ne slabosti (Jackson, 2001, 236).

Dakle, svrha KSM-a je da na validan način upravlja raznolikošću sistemskih metodologija, tj. da istraži načine primerene upotrebe različitih sistemskih metodologija, metoda i modela da bi se odgovorilo na kompleksnost, izmenljivost i raznovrsnost problemskih 
situacija sa kojima se suočavaju menadžeri $u$ savremenim organizacijama (Jackson, 2010, 136). Zapravo, kritičko sistemsko mišljenje predstavlja odgovarajući tok $\mathrm{u}$ okviru savremenog Management Science-a, koji je zasnovan na sledećim principima, tj. obavezanostima: kritička svesnost, društvena svesnost, ljudska emancipacija, komplementarizam na nivou metodologija, i teorijski komplementarizam (Jackson, 1994, 223-226; Petrović, 2010, 74-77).

Za kontekst datih razmatranja, od posebne važnosti je kritička svesnost koja se odnosi na razumevanje snaga i slabosti teorijskih utemeljenja različitih sistemskih metodologija, i istraživanje korisnosti upotrebe različitih sistemskih modela, metoda, i tehnika u okviru različitih sistemskih metodologija. Respektovanje kritičke svesnosti rezultiralo je kontinuiranim vrednovanjem prednosti i nedostataka svih sistemskih prilaza, i saznanjem da sistemske metodologije treba kombinovano koristiti u upravljanju kompleksnim problemskim situacijama.
Kombinovano korišćenje sistemskih metodologija, a posebno metodologija koje pripadaju različitim sistemskim paradigmama, može se sprovesti na različite načine. Zapravo, pre svega, jedna metodologija može da bude dominantna, a druga, metodologija podrške. Takođe, jedna metodologija ili delovi metodologije mogu biti inkorporirani u drugu metodologiju, ili se mogu kombinovano koristiti odgovarajući instrumenti neke metodologije, a ne kompletna metodologija, itd. (Mingers, 1997, 7; Mingers \& Brocklesby, 1997, 491). U Tabeli 1 prikazani su neki od mogućih tipova kombinovanja metodologija, tj. multimetodološkog istraživanja.

Shodno navedenom, a u cilju identifikovanja pretpostavki, uslova, načina, prednosti i nedostataka kombinovanja ITSP-metodologije i Organizacione kibernetike, od odgovarajućeg značaja je precizirati ključna teorijsko-metodološka određenja navedenih sistemskih prilaza.

Tabela 1 Različiti tipovi multimetodološkog istraživačkog dizajna

\begin{tabular}{|c|c|c|c|}
\hline Vrsta dizajna & Kombinovanje metodologija & Ilustracija & Primer \\
\hline Sekvencijalni & $\begin{array}{l}\text { Metodologije se primenjuju } \\
\text { određenim redosledom, } \\
\text { pri čemu rezultati jedne } \\
\text { metodologije utiču na drugu } \\
\text { metodologiju. }\end{array}$ & $\begin{array}{l}\text { Uraditi statističku analizu upitnika, a zatim } \\
\text { slede dodatni intervjui da bi se bolje razumeli } \\
\text { rezultati; ili } \\
\text { sprovesti etnografska istraživanja i analizu } \\
\text { sadržaja da bi se dizajnirao upitnik. }\end{array}$ & $\begin{array}{l}\text { (Markus, 1994) } \\
\text { (Ngwenyama \& Lee, 1997) } \\
\text { (Carlson \& Davis, 1998) }\end{array}$ \\
\hline Paralelni & $\begin{array}{l}\text { Paralelna primena metodologija, } \\
\text { gde metodologije međusobno } \\
\text { utiču jedna na drugu. }\end{array}$ & $\begin{array}{l}\text { Posmatranje i snimanje uz intervjuisanje i } \\
\text { kognitivno mapiranje korisnika. }\end{array}$ & $\begin{array}{l}\text { (Trauth \& O'Connor, 1991) } \\
\text { (Trauth \& Jessup, 2000) }\end{array}$ \\
\hline $\begin{array}{l}\text { Dominantni } \\
\text { (imperijalistički) }\end{array}$ & $\begin{array}{l}\text { Jedna metodologija se koristi } \\
\text { kao dominantna, sa određenim } \\
\text { doprinosima druge. }\end{array}$ & $\begin{array}{l}\text { Intenzivno istraživanje korišćenjem } \\
\text { etnografske analize ili posmatranje učesnika } \\
\text { sa određenim statističkim analizama. }\end{array}$ & $\begin{array}{l}\text { (Siliance \& Mouakket, } \\
\text { 1997) }\end{array}$ \\
\hline Multimetodologija & $\begin{array}{l}\text { Kombinovanje metodologija iz } \\
\text { različitih paradigmi za određeni } \\
\text { zadatak. }\end{array}$ & $\begin{array}{l}\text { Intervjui, analiza podataka i upitnici } \\
\text { kombinovani sa izvornim definicijama i } \\
\text { konceptualnim modelima Metodologije soft } \\
\text { sistema i Strategijskim izborom. }\end{array}$ & (Ormerod, 1995) \\
\hline $\begin{array}{l}\text { Istraživanje na više } \\
\text { nivoa }\end{array}$ & $\begin{array}{l}\text { Kombinovanje metodologija } \\
\text { u simultanom istraživanju na } \\
\text { različitim nivoima organizacije. }\end{array}$ & $\begin{array}{l}\text { Anketiranje zaposlenih i intervjui/kognitivno } \\
\text { mapiranje sa supervizorima i menadžerima. }\end{array}$ & $\begin{array}{l}\text { (Taylor \& Tashakkori, } \\
\text { 1997) }\end{array}$ \\
\hline
\end{tabular}




\section{KLJUČNA TEORIJSKO-METODOLOŠKA ODREĐENJA ITSP-METODOLOGIJE I ORGANIZACIONE KIBERNETIKE}

\section{ITSP-metodologija}

ITSP-metodologija predstavlja relevantnu interpretativnu sistemsku metodologiju bavljenja nestrukturiranim, nedovoljno dobro definisanim problemima, tj. problemskim situacijama $u$ preduzećima. Reč je o metodologiji primerenoj pluralističkim problemskim situacijama, u kojima je fokus na političkim i kulturalnim aspektima organizacije. Shodno tome, ova metodologija apstrahuje strukturu i funkcionisanje organizacija, tj. probleme koji proizilaze iz kompleksne prirode istraživanih područja.

U teorijskom smislu, za ITSP-metodologiju je od ključne važnosti da problemske situacije treba istraživati sa različitih aspekata. Odnosno, od esencijalne važnosti je drugačije, dijalektičko shvatanje objektivnosti: Nekom preovlađujućem shvatanju sveta - teza, treba suprotstaviti drugačije shvatanje sveta koje je utemeljeno na drugačijim pretpostavkama - antiteza, da bi se došlo do uslovno objektivnije procene istraživane situacije koja sadrži elemente i teze i antiteze, ali je istovremeno izvan njih - sinteza (Jackson, 2003, 139-140).

Sa opredeljenim shvatanjem objektivnosti, kao ključnim teorijskim postulatom ITSP-metodologije, korespondiraju principi participativnosti, oprečnosti i integrativnosti (Mason \& Mitroff, 1981, 16; Petrović, 2010, 447-448). Reč je o tome da u upravljanju problemskim situacijama $\mathrm{u}$ preduzećima treba uključiti uključiti različite nivoe i grupe u organizaciji, kao i ostale relevantne stakeholder-e, čije su percepcije i shvatanja međusobno suprotstavljena, ali koje treba na odgovarajući način povezati, tj. obezbediti njihovu sintezu. Osim navedenih, važan princip je i podržavanje upravljačkog mišljenja koje se tiče činjenice da izloženost menadžera različitim pretpostavkama omogućava bolje razumevanje organizacije, njenih politika i strategija.
U upravljanju problemskim situacijama, ITSPmetodologija se primenjuje kroz sledeće četiri faze (Mitroff, Emshoff \& Kilmann, 1979, 584; Jackson, 2003, 143): formiranje grupa, identifikovanje pretpostavki, dijalektička debata i sinteza. Grupe se formiraju vodeći računa o tome da se minimiziraju razlike i konflikti unutar grupe, ali da se maksimiraju razlike između grupa (Elrod \& Moss, 1998, 284). Proces identifikovanja pretpostavki sastoji se od potprocesa analize stakeholder-a, specificiranja pretpostavki i procenjivanja pretpostavki (Mitroff et al, 1979, 586). Najvažniji kriterijum o kome treba voditi računa kod analize stakeholder-a je na koji način oni mogu da utiču na određenu strategiju i na koji način ta strategija utiče na njih, kako bi svaka grupa generisala listu pretpostavki na kojima se temelji određena strategija ili politika. Iako broj pretpostavki koje treba specificirati nije ograničen, da se proces ne bi opteretio prevelikim brojem pretpostavki, inicijalno se radi sa pet pretpostavki. Za ITSP-metodologiju je od ključne važnosti da se pretpostavke procene vodeći računa o relativnoj važnosti pretpostavke, odnosno njenoj važnosti za uspeh ili neuspeh određene strategije, i njenoj relativnoj izvesnosti, tj. pouzdanosti da je pretpostavka opravdana.

Dijalektička debata, kao ključni deo ove metodologije, započinje tako što predstvanik svake grupe izloži najvažnije pretpostavke koje podržavaju određenu strategiju. Nakon toga se razvija diskusija, koja može biti različita u zavisnosti od sledećeg (Mason \& Mitroff, 1981, 105-106): grupe mogu da identifikuju isti skup stakeholder-a, ali različite pretpostavke koje se na njih odnose; zatim, grupe mogu esencijalno da dele isti skup stakeholder-a i isti skup pretpostavki, ali da potpuno različito procene pretpostavke; takođe, različite grupe mogu imati različite stakeholder-e, i samim tim i različite pretpostavke.

Za postizanje dijalektičke sinteze, od ključnog značaja je modifikacija pretpostavki, odnosno potrebno je da grupe ublaže svoje pretpostavke do one tačke u kojoj, ukoliko se dalje modifikuju, neće više podržavati određenu strategiju. Članovi određene grupe ne moraju da promene svoje percepcije i perspektive, već da budu spremni da u proces odlučivanja uključuju oprečne perspektive (Van der Veen, 2003). Isto tako, ukoliko se ne postigne sinteza, potrebno je identifikovati tačke 
neslaganja i diskutovati o mogućim načinima njihovog otklanjanja.

\section{Organizaciona kibernetika}

Kao predstavnik funkcionalističke sistemske paradigme, Organaciona kibernetika (OK) je fokusirana na istraživanje strukture i funkcionisanja savremenih preduzeća. Zapravo, posredstvom Modela sistema sposobnog da opstane (SSO model) - svog ključnog metodološkog instrumenta, OK obezbeđuje moćan instrumentarijum dijagnostikovanja problema u strukturi i funkcionisanju preduzeća.

Teorijsko jezgro Organizacione kibernetike čine Zakon potrebne varijetetnosti i princip rekurzije. Zakon potrebne varijetetnosti generalno glasi: „Samo varijetetnost može uništiti varijetetnost" (Ashby, 1966, 207). To dalje znači da se mora smanjiti varijetenost visoko varijetetnih sistema i povećati varijetetnost nisko varijetetnih sistema. Ovaj proces, označen kao upravljanje varijetetnošću, može biti efektivan ako se organizacije bave samo onim delom okruženja koji proizvodi smetnje na koje se organizacija mora odazvati da bi opstala. Reč je o tzv. rezidualnoj varijetetnosti okruženja. Analogno važi i za organizaciju i upravljanje njome, za koje je relevantna tzv. rezidualna varijetetnost organizacije, odnosno, ona varijetetnost koja je ostala neapsorbovana procesima samoorganizacije i samoregulacije (Schwaninger, 2000, 211; Schwaninger, 2006, 15). Princip rekurzije se odnosi na činjenicu da su sistemi hijererhijski uređeni, tj. da su svi sistemi sastavljeni od niza podsistema, od kojih svaki ima sopstvenu organizaciju i sopstvene karakteristike regulacije. Istovremeno, ti sistemi su deo nekog supra sistema, tj. sistema višeg reda. Svaki od podsistema je, takođe, sastavljen od odgovarajućih podsistema i tako dalje do najnižih nivoa (Beer, 1994a, 228).

Izvorno razvijen u S. Beer-ovoj trilogiji o Modelu sistema sposobnog da opstane (Beer, 1994a; Beer, 1994b; Beer, 1994c), SSO model obuhvata sledećih pet ključnih podsistema (Brocklesby \& Cummings, 1996, 51; Howerstadt, 2010, 89; Azadeh, Darivandi \& Fathi, 2012, 67-68):
- podsistem $\mathrm{S}_{1}$ koji reprezentuje funkciju implementacije, odnosno operacione elemente koji se direktno suočavaju sa eksternim okruženjem;

- podsistem $\mathrm{S}_{2}$ ili funkcija koordinacije koja obezbeđuje harmonično delovanje operacionih elemenata;

- podsistem $\mathrm{S}_{3}$ - funkcija kontrole koja održava i alocira resurse na operacione elemente, uz dodatak segmenta $\mathrm{S}_{3}{ }^{*}$ koji reprezentuje odgovarajuće revizione kanale pomoću kojih se prati funkcionisanje operacionih elemenata;

- podsistem $\mathrm{S}_{4}$ - funkcija izveštavanja koja posmatra sistem kao celinu - njegove strateške mogućnosti, pretnje i buduća usmeravanja i

- podsistem $\mathrm{S}_{5}$ ili funkcija identiteta kojom se opredeljuje svrha sistema.

SSO model se primenjuje u (re)dizajniranju organizacije kroz sledeća tri relevantna potprocesa (Flood, 1995, 149; Petrović, 2010, 399-403): identifikovanje sistema, dijagnosticiranje sistema i redizajniranje (ukoliko je potrebno). Identifikacija sistema započinje preciziranjem svrhe ili razloga postojanja organizacije, a nastavlja se izdvajanjem sledećih rekurzivnih nivoa: sistem $\mathrm{u}$ fokusu, $\mathrm{tj}$. sistem koji treba da ostvari prethodno fomulisanu svrhu i iz svrhe izvedene ciljeve - rekurzivni nivo 1; supra sistem sistema $\mathrm{u}$ fokusu, tj. relevantno okruženje sistema $u$ fokusu - rekurzivni nivo 0; operacioni elementi sistema $\mathrm{u}$ fokusu, $\mathrm{tj}$. podsistemi sistema u fokusu - rekurzivni nivo 2 .

Posle sprovedene identifikacije $\mathrm{u}$ procesu korišćenja SSO modela sledi potproces dijagnoze, kojim se analiziraju, pre svega, segmenti $S_{1^{\prime}} S_{2^{\prime}} S_{3^{\prime}} S_{4}$ i $S_{5}$ sistema $\mathrm{u}$ fokusu, a zatim svi informacioni kanali, prenosnici i kontrolne petlje. Potproces dijagnoze podrazumeva da se data organizacija poredi sa SSO modelom i utvrđuju određeni problemi u strukturi i funkcionisanju date organizacije. Naime, dijagnozom mogu biti identifikovani sledeći problemi (Peréz Ríos, 2010, 1544-1547): pogrešno opredeljeni nivoi rekurzije, neadekvatno opredeljen identitet, što podrazumeva da dve ili više različitih koncepcija identiteta produkuju konflikte unutar organizacije; segment $\mathrm{S}_{4}$ ne postoji uopšte ili ako postoji ne funkcioniše 
adekvatno; neadekvatan stil upravljanja, kojim se ograničava autonomija segmenta $\mathrm{S}_{1}$; autoritaran segment $S_{2}$; dominantnost segmenta $S_{1}$; nekontrolisani rast i aktivnost određenih delova organizacije; komunikacioni kanali u sistemu i između sistema i okruženja ne korespondiraju informacionim tokovima, itd.

Kada se $u$ organizaciji otkriju neki od pomenutih problema, pristupa se redizajniranju sistema, kao poslednjem potprocesu $\mathrm{u}$ korišćenju SSO modela (Flood, 1995, 159). Prvi korak u redizajniranju sistema je dijagramska prezentacija identifikovanih problema organizacije. Dalje se vrši njihovo proučavanje i analiza. Pri tome je od velikog značaja formulisanje određenih procedura i to: procedura za procese operacionih elemenata i procedura za upravljačke funkcije.

\section{PRETPOSTAVKE I USLOVI KOMBINOVANJA ITSP-METODOLOGIJE I ORGANIZACIONE KIBERNETIKE}

Respektujući ključna teorijsko-metodološka određenja ITSP-metodologije i OK, može se zaključiti da je ITSPmetodologija reprezent soft sistemskog mišljenja, dok je Organizaciona kibernetika predstavnik hard sistemskog mišljenja. Shodno tome, za sinergijsko korišćenje ove dve metodologije, od relevantne važnosti su sledeće razlike između hard i soft sistemskog mišljenja (Petrović, 2010, 46; Zexian \& Xuhui, 2010, 140145, Zlatanović, 2010, 98):

Ključna razlika između hard sistemskog mišljenja (HSM) i soft sistemskog mišljenja (SSM) se ogleda u samoj interpretaciji koncepta sistema. HSM posmatra sistem kao objektivni deo realnosti. Nasuprot tome, SSM tretira sistem kao epistemološki koncept koji predstavlja subjektivnu konstrukciju ljudi, pre nego objektivni entitet realnog sveta.

Osim navedenog, HSM i SSM se zasnivaju na različitoj teorijskoj osnovi i koriste različite metode analize. HSM pretpostavlja da sistem treba da ima jasnu strukturu i jasno specificiran cilj. Međutim, ovakva vrsta razmišljanja koja podrazumeva optimizaciju ne može da reši kompleksne društvene probleme zato što ignoriše različite percepcije, vrednosti i interese koje postoje $\mathrm{u}$ organizacijama. Nasuprot tome, $\mathrm{u}$ SSM-u predmet istraživanja nije jedan jasno definisani problem, već problemske situacije shvaćene kao sistemi problema. Fokus je na unapređivanju, a ne na optimizaciji, odnosno, fokus je na odgovarajućem procesu učenja.

Konačno, HSM i SSM su oslonjeni na različite principe sticanja znanja, odnosno, imaju različite epistemološke pristupe. HSM posmatra onoga ko interveniše $u$ sistemu kao nekog ko nije sastavni deo sistema. HSM je u skladu sa tradicionalnom epistemologijom u kojoj su subjekat i objekat istraživanja odvojeni, odnosno, u kojoj se ignorišu veze koje postoje između subjekta i objekta istraživanja. Nasuprot tome, SSM respektuje odnos između istraživača kao subjekta istraživanja i problemske situacije kao objekta istraživanja. Dakle, istraživač je involviran u situaciju koja se istražuje. Samim tim, SSM podrazumeva korišćenje akcionog istraživanja i interpretativnu paradigmu u istraživanju i unapređivanju problemskih situacija.

U kontekstu datih razmatranja, od odgovarajuce je važnosti činjenica da je ITSP-metodologija, kao reprezent soft sistemskog mišljenja, usmerena na istraživanje različitih percepcija, shvatanja, pretpostavki koje relevantni stakeholder-i imaju o određenim problemskim oblastima u preduzećima, odnosno, o odgovarajućim predlozima za unapređenje poslovanja preduzeća. Nasuprot tome, iako je reprezent hard sistemskog mišljenja, Organizaciona kibernetika se razlikuje od nekih drugih hard sistemskih prilaza poput Sistemske analize, Sistemskog inženjeringa, Tradicionalnih operacionih istraživanja, po svom strukturalističkom prilazu konstrukciji teorije sistema. Veruje se da je moguće otkriti strukturalističke zakonitosti koje su u osnovi efektivnosti sistema i njihovu osposobljenost da opstanu i razvijaju se. Ipak, sa aspekta praktičnog korišćenja, OK zavisi od postojanja unapred definisanog neposrednog cilja i od pojedinaca i grupa koji se slažu o određenom neposrednom cilju. Shodno tome, OK se može tretirati kao „metodološki instrumentarijum za unapređivanje dizajna, kontrole, funkcionisanja sistema usmerenih na dostizanje unapred određenih rezultata" (Petrović, 2010, 53). 
Vodeći računa o identifikovanim razlikama između hard i soft sistemskih prilaza, i oslanjajući se na relevantna teorijsko-metodološka određenja ITSPmetodologije i Organizacione kibernetike, tj. njenog osnovnog metodološkog instrumenta - SSO modela, mogu se opredeliti ključne manjkavosti datih sistemskih metodologija relevantne za njihovo kombinovano korišćenje. Zapravo, od ključne važnosti za njihovo kombinovanje su sledeća ograničenja.

Pre svega, ITSP-metodologija se fokusira na odnose učesnika, tj. na istraživanje različitih percepcija, perspektiva, interpretacija određenih problemskih situacija u preduzećima. U tom smislu, ITSP apstrahuje dimenziju sistemnosti, tj. strukturu i funkcionisanje organizacija. Dakle, u kreativnom upravljanju problemskim situacijama u preduzećima, ITSPmetodologija se efektivno suočava sa pluralizmom, ali ne i sa kompleksnom prirodom problemskih situacija. Nasuprot tome, Organizaciona kibernetika akcenat stavlja na organizacionu strukturu i komunikacione procese i ne uvažava, $u$ dovoljnoj meri, osmišljenu ulogu pojedinaca u organizacijama. Naime, koncepcija modela nalaže da se slede unapred određeni ciljevi organizacije, a delovima organizacije na koje je kontrola delegirana, ostavljena je jedino sloboda u traganju za alternativnim načinima ostvarivanja tih ciljeva. $\mathrm{Na}$ taj način, pažnja se posvećuje realizaciji ciljeva, a ne načinu na koji su ti ciljevi postavljeni. Zapravo, fokus je na dimenziji sistema, dok se dimenzija odnosa učesnika zanemaruje. Odnosno, OK može efektivno da preradi kompleksnost problemskih situacija, ali ne može da se suoči sa pluralističkom prirodom problemskih situacija.

Otklanjanje navedenih ograničenja može se postići njihovom sinergijskom upotrebom. Uslovi sinergijskog korišćenja ITSP-a i OK zavise od same prirode istraživanih problemskih situacija, tj. od načina na koji su opredeljeni ciljevi. Naime, ako je u nekom preduzeću jasno opredeljen cilj, tj. svrha i iz te svrhe proizilazi jasno identifikovana strategija, odnosno $\mathrm{u}$ istraživanom preduzeću postoji opšta saglasnost relevantnih stakeholder-a oko ciljeva, politika ili strategija, onda će individualna primena OK dati bolje rezultate. U tom slučaju, cilj je jasno identifikovan i potrebno je dizajnirati odgovarajuću strukturu i opredeliti odgovarajuće funkcionisanje organizacije koje će omogućiti efikasno ostvarivanje unapred identifikovanog cilja.

Međutim, ako postoje različiti interesi, percepcije, shvatanja toga šta je svrha, tj. koji su ciljevi koje preduzeće treba da sledi, onda će kombinovna upotreba ITSP-a i OK dati bolje rezultate. Zapravo, vodeći računa o tome da problemi u preduzećima, generalno, poseduju svojstva kompleksnosti i pluralizma, onda se može zaključiti da individualna primena ITSP-a ili OK ne može da pomogne u adekvatnom upravljanju ovim problemskim situacijama.

Respektujući navedeno, u kombinovanoj upotrebi ITSP-a i OK treba voditi računa o sledećim ključnim principima: participativnost, oprečnost, integrativnost; Zakon potrebne varijetetnosti, rekurzija i feedback. Princip participativnosti podrazumeva uključivanje svih relevantnih stakeholder-a u proces odlučivanja o odgovarajućim ciljevima i strategijama, tj. $u$ opredeljivanju odgovarajuce politike organizacije. Princip oprečnosti podrazumeva identifikovanje različitih, suprotstavljenih shvatanja problemske situacije koja je predmet razmatranja, tj. suprotstavljenih stavova i percepija politike, ciljeva i strategije koje određeno preduzeće treba da sledi. Principom integrativnosti se identifikovane razlike pokušavaju da prevaziđu i da se omogući određeno prilagođavanje stavova stakeholder-a, tj. da se obezbedi određena sinteza shvatanja.

Respektovanje Zakona potrebne varijetetnosti omogućava da se adekvatno preradi kompleksnost istraživane problemske situacije, tj. da se omogući određeno usklađivanje međusobno različitih varijetetnosti organizacije, procesa upravljanja njome i relevantnog okruženja. Princip rekurzije sugeriše odgovarajući proces otkrivanja kompleksnosti $\mathrm{u}$ datoj organizaciji i identifikovanje rekurzivnih nivoa. Konačno, u obezbeđivanju efikasnog ostvarivanja ciljeva, od relevantnog značaja je odgovarajući feedback kontrolni mehanizam, kojim se identifikuju eventualna odstupanja od željenih rezultata i opredeljuju odgovarajuće korektivne akcije, koje kreativno unapređuju proces upravljanja problemskim situacijama u preduzećima. 
Dakle, kombinovanje ITSP-a i OK može biti sprovedeno $\mathrm{u}$ onim situacijama kada je fokus kako na raznolikosti mogućih viđenja participanata, tako i na efikasnosti i adaptibilnosti. Neka od područja primene kombinovanja ITSP-a i OK su: opredeljivanje i implementacija odgovarajuće strategije razvoja informacionih sistema (Clarke \& Lehaney, 2000), identifikovanje i sprovođenje odgovarajućeg pristupa redizajniranju organizacione strukture (Flood, 1995), upravljanje znanjem (Pollalisa \& Dimitrou, 2008), itd.

\section{POTENCIJALNI NAČIN}

\section{KOMBINOVANJA ITSP-METODOLOGIJE I ORGANIZACIONE KIBERNETIKE}

U kombinovanoj upotrebi interpretativnih i funkcionalističkih sistemskih prilaza, uočeno je da se bolji rezultati postižu kada interpretativni prilaz prethodi funkcionalističkom prilazu (Brown, Cooper \& Pidd, 2006, 667). Navedeno znači da interpretativni prilaz treba iskoristiti kako bi se dao smisao istraživanoj situaciji i kako bi pomogao da se uspostavi odgovarajući kontekst u okviru kog će se upotrebiti funkcionalistički prilaz. Shodno tome, a vodeći računa o ključnim svojstvima, dometima i ograničenjima ITSP-metodologije i OK, u radu je opredeljen sledeći način sinergijskog korišćenja ova dva prilaza.

Obuhvatajući mišljenja i percepcije različitih stakeholder-a, tj. identifikujući različite strategijske pretpostavke, ITSP-metodologija, kroz proces dijalektičke debate dovodi do sinteze, odnosno, usaglašavanja suprotstavljenih pretpostavki. Time se omogućava definisanje strategije koju preduzeće, suočeno sa određenim problemskim situacijama, treba da sledi. Oslanjajući se na identifikovanu strategiju, OK će - posredstvom Modela sistema sposobnog da opstane - omogućiti efikasnost i adaptibilnost istraživanog preduzeća. Zapravo, ako se u podsistemu $\mathrm{S}_{5}$ SSO modela, koji reprezentuje funkciju zaduženu za formulisanje politika i strategija, primeni ITSP, onda se time stvara osnova kombinovanog korišćenja ova dva prilaza. Na taj način, otklanjaju se odgovarajuće manjkavosti OK, vezane za nemogućnost obuhvatanja različitih stanovišta, kao i ograničenja ITSP-a, koja se tiču strukture i funkcionisanja preduzeća.

Moguće kombinovano, tj. sinergijsko korišćenje ova dva prilaza podrazumeva sledeće dve ključne faze:

- identifikovanje ciljeva, tj. strategija koje preduzeće suočeno sa nekom problemskom situacijom treba da sledi i opredeljivanje odgovarajućih rekurzivnih nivoa, $\mathrm{i}$

- dizajniranje odgovarajuće organizacione strukture i načina funkcionisanja kojim će se omogućiti efikasno ostvarivanje ciljeva, tj. efikasna implementacija opredeljene strategije preduzeća.

U tom smislu, prva faza podrazumeva upotrebu ITSPmetodologije kroz faze formiranja grupa, specificiranja pretpostavki, dijalektičke debate i sinteze, a druga faza zahteva primenu OK, tj. SSO modela, kao podršku ITPS-u u preradi kompleksnosti. Dakle, ITSP se, kao relevantan soft sistemski prilaz upotrebljava kako bi se obezbedio kontekst u okviru kog se može upotrebiti OK, kao hard, tj. funkcionalistički sistemski prilaz. Shodno tome da je u primeni SSO modela prva faza zapravo identifikacija sistema, tj. identifikacija svrhe i ciljeva, i da je za to u okviru SSO modela zadužen segment $S_{5^{\prime}}$ kombinovano korišćenje ove dve metodologije se može prikazati u koncepcijskom okviru SSO modela (Slika 1).

Kao što se sa Slike 1 može uočiti, u segmentu $S_{5}$ treba najpre primeniti ITSP-metodologiju. Kada se, kroz adekvatno uključivanje svih relevantnih stakeholder-a, podeljenih $\mathrm{u}$ različite grupe, dijalektičkom sintezom obezbedi formulisanje takve poslovne strategije koja je prihvatliiva stakeholder-ima i čijom će implementacijom biti unapređeno funkcionisanje organizacije, pristupa se dijagnostikovanju, tj. opredeliivanju ostalih relevantnih podsistema SSO modela. Od posebnog značaja za sam proces formulisanja poslovne strategije je povezanost podsistema $S_{5}$ i podsistema $S_{4^{\prime}}$ shodno činjenici da podsistem $S_{4}$ prikuplja relevantne informacije o pretnjama i šansama iz okruženja, kao i snagama i slabostima sistema.

U opredeljivanju ostalih podsistema SSO modela potrebno je, pre svega, opredeliti odgovarajuće 


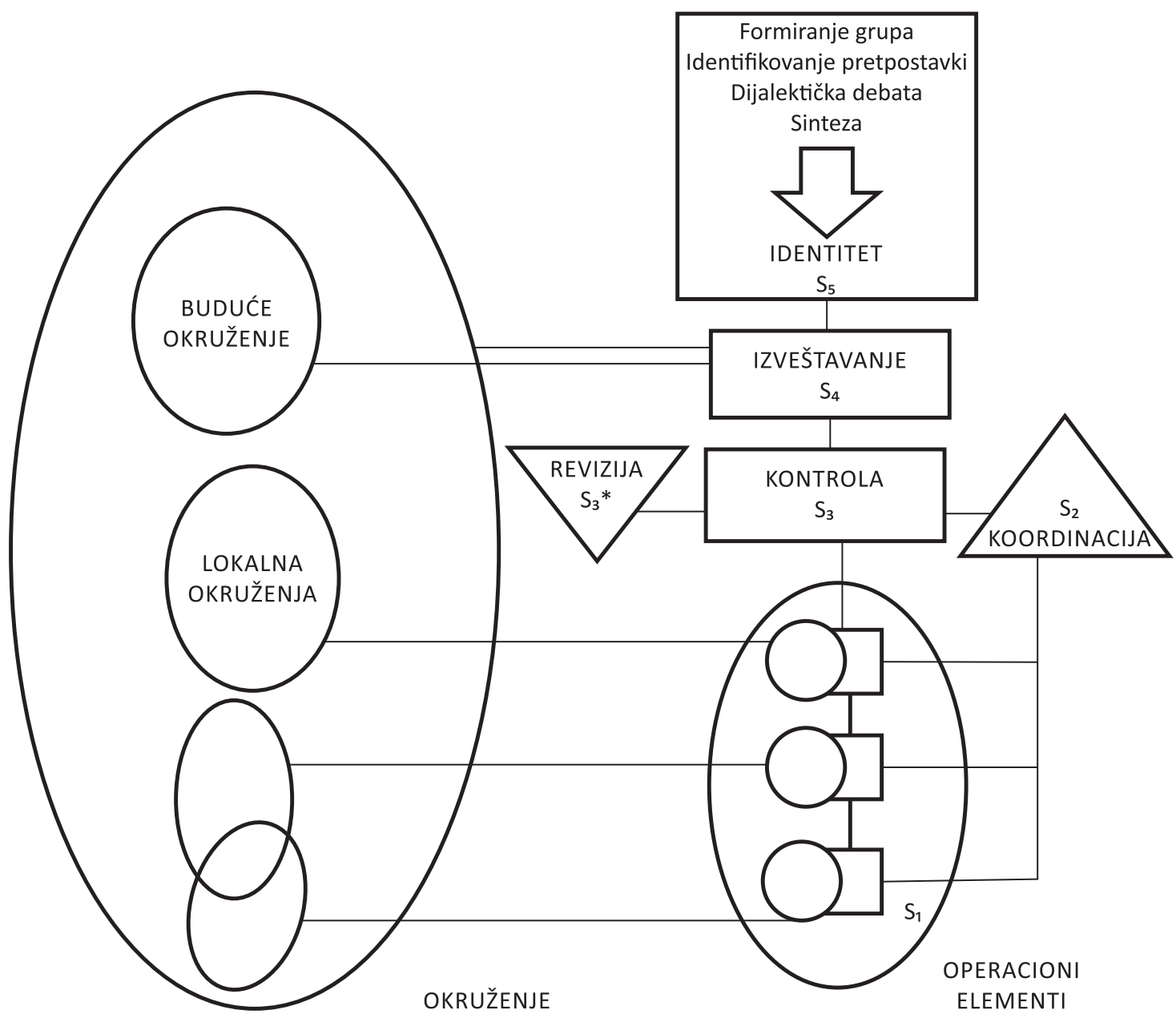

Slika 1 Kombinovanje ITSP-metodologije i OK u koncepcijskom okviru SSO modela

Izvor: Autor, prema Brocklesby \& Cummings, 1996, 50

operacione elemente koji će omogućiti ostvarivanje identifikovanih ciljeva i strategija (podsistem $\mathrm{S}_{1}$ ), zatim način na koji treba da budu koordinisani (podsistem $\mathrm{S}_{2}$ ) i kontrolisani (podsistem $\mathrm{S}_{3}$ ) i identifikovati različite šanse, pretnje, snage i slabosti datog preduzeća u implementaciji identifikovane strategije, tj. $\mathrm{u}$ realizaciji opredeljenih ciljeva (podsistem $\mathrm{S}_{4}$ ). Kada se sprovedu sve aktivnosti koje podrazumeva primena ITSP-metodologije pristupa se identifikovanju odgovarajućih rekurzivnih nivoa. Da bi se efikasno sproveli formulisani ciljevi, strategije i/ili politike potrebno je opredeliti sledeće:
- sistem u fokusu - rekurzivni nivo 1 (na primer, preduzeće kao celina),

- supra sistem sistema u fokusu - rekurzivni nivo 0 (na primer, industrijska grana u kojoj preduzeće posluje), i

- operacione elemente sistema u fokusu - rekurzivni nivo 2 (na primer, organizacioni divizioni ili delovi).

Sledeći korak u sinergijskoj upotrebi ITSP-metodologije i OK je dijagnostikovanje problema $u$ strukturi i funkcionisanju istraživanog preduzeća. Zapravo, 
procenjuje se postojeće stanje, odnosno, sposobnost organizacije da implementira prethodno donete odluke, tj. da ostvari postavljene ciljeve/strategije. Data organizacija se poredi sa SSO modelom i utvrđuju eventualna odstupanja. $U$ tom smislu, pažljivo se istražuju segmenti $S_{1}, S_{2}, S_{3}$ i $S_{4}$.

Dijagnoza podistema $S_{1}$ se odnosi na postojeće operacione elemente sistema $u$ fokusu, $t j$. odgovarajuće organizacione delove koji su zaduženi za ostvarivanje identifkovanih ciljeva/strategija. U tom smislu, procenjuje se da li izdvojeni organizacioni delovi predstavljaju sami za sebe sisteme sposobne da opstanu. To se sprovodi identifikovanjem njihovog lokalnog menadžmenta, okruženja, autonomije, kao i odgovarajućih ograničenja. Na taj način mogu se izvesti zaključci o tome u kojoj meri dati operacioni elementi apsorbuju kompleksnost sa kojom se organizacija suočava.

$\mathrm{U}$ podsistemu $\mathrm{S}_{2}$ dijagnoza podrazumeva identifikovanje odgovarajućih povezanosti između organizacionih jedinica u preduzeću, tj. načina na koji se koordinira funkcinisanje operacionih elemenata. Od odgovarajuće je važnosti utvrditi da li u datoj organizaciji ovakav segment uopšte postoji prema koncepciji SSO modela, kao i da li postoje određene koordinacione procedure i timovi, kako se primenjuje autoritet, šta su izvori smetnji i konflikata, itd.

Kontrolna funkcija, $\mathrm{tj}$. podsistem $\mathrm{S}_{3}$ se dijagnostikuje kroz utvrđivanje: onih koji obavljaju aktivnosti kontrole u preduzeću, načina na koji se alociraju resursi, nivoa samostalnosti, tj. slobode sa kojom raspolažu operacioni elementi, kao i karakteristika ove funkcije u preduzeću (centralizovanana ili decentralizovana, birokratska ili ne).

Specificiranje šansi, pretnji, snaga i slabosti istraživanog preduzeća predstavlja osnovu za dijagnozu segmenta $S_{4}$. Takođe, potrebno je utvrditi da li takav segment postoji u preduzeću, da li se i kako prikupljene informacije o snagama i slabostima, šansama i pretnjama prosleđuju onima koji donose odluke, itd.

Budući da kombinovana upotreba ITSP-a i OK podrazumeva primenu ITSP-a u segmentu $\mathrm{S}_{5}$ i shodno tome, otklanjanje mogućih nedostataka, poput (ne) uključivanja svih relevantnih stakeholder-a u procese odlučivanja ili neadekvatno opredeljenu politiku, tj. strategiju i slično, dijagnoza ovog segmenta se delimično sprovedi u prvoj fazi kombinovanja ITSP-a i OK. Međutim, dijagnoza ove funkcije se može dalje sprovesti u smislu utvrđivanja realne uključenosti stakeholder-a u procese formulisanja politka i strategija, tj. procene da li su obuhvaćeni svi relevantni stakeholder-i, da li opredeljena organizaciona kultura predstavlja podršku implementaciji definisane politike, ciljeva ili strategije, kao i posvećenosti stakeholder-a u implementaciji izabrane strategije.

Probleme u funkcionisanju, otkrivene prethodno opisanim procesom dijagnoze je potrebno grupisati i predložiti eventualni redizajn organizacije, tako da funkcioniše u skladu sa odgovarajućim kibernetskim principima $\mathrm{i}$ zakonima. Kao $\mathrm{i} u$ individulanoj upotrebi OK, od odgovarajuće su važnosti procedure operacionih elemenata i procedure upravljačkih funkcija.

\section{PRIMER INTEGRISANE PRIMENE ITPS- METODOLOGIJE I ORGANIZACIONE KIBERNETIKE U PREDUZEĆU}

Opisani način kombinovanja ITSP-a i OK može biti ilustrovan na sledećem primeru moguće upotrebe navedenih prilaza $u$ procesu formulisanja i implementacije strategije $u$ uslovima Globalne ekonomske krize, u izabranom preduzeću A, koje se bavi prometom rezervnih delova za različite kategorije vozila i za potrebe prve ugradnje (Zlatanović, 2015, 250-289).

Pre svega, $\mathrm{u}$ okviru moguće upotrebe ITSPmetodologije u preduzeću A, sproveden je intervju sa top menadžmentom kako bi se obezbedila saznanja o tome sa kojim se problemima suočava izabrano preduzeće usled globalne ekonomske krize. Na taj način, došlo se do saznanja da je ekonomska kriza negativno uticala na poslovanje datog preduzeća, tj. preduzeće se suočilo sa sledećim problemima: pad kupovne moći, finansijski problemi pojedinih kupaca (na primer, blokade računa i nemogućnost izmirivanja obaveza), nedovoljno novih, likvidnih kupaca, kao i nemogućnost obnove voznog parka. Navedeno je 
rezultiralo padom prodaje i padom rentabilnosti. Dakle, preduzeće se suočilo sa prvim simptomima krize, ali mu nije ugrožen opstanak. U datoj situaciji, menadžment preduzeća odlučuje da proširi svoje poslovanje $\mathrm{i}$ da uđe $\mathrm{u}$ nove poslove. Sa ovako opredeljenom strategijom postojalo je neslaganje, pre svega, internih stakeholder-a. Odnosno, postojala su suprotstavljena shvatanja vlasnika i top menadžmenta preduzeća i ostalih zaposlenih (na primer, top menadžmenta i srednjeg menadžmenta).

Opisana problemska situacija predstavlja višeznačnu, tj. pluralističku problemsku situaciju u kojoj se može primeniti ITSP-metodologija. Intervju sa top menadžmentom istraživanog preduzeća omogućio je, osim saznanja relevantnih za formulisanje problemske situacije i predloženog rešenja problema, i identifikovanje ključnih pretpostavki koje podržavaju predloženu strategiju ulaska u nove poslove, kao i alternativnu strategiju.

Na primer, jedna od ključnih pretpostavki na kojoj top menadžment zasniva strategiju ulaska $u$ nove poslove je da će na taj način smanjiti rizik. Isto tako, menadžment je pošao od pretpostavke da će time povećati tražnju za svojim proizvodina, što će dovesti do boljih poslovnih rezultata, i slično. Uz navedeno, od top menadžmenta preduzeća A dobijena su saznanja o tome koja preduzeća predstavljaju relevantne stakeholder-e, tj. koja preduzeća su najvažniji kupci, dobavljači i konkurencija. $\mathrm{Na}$ osnovu dobijenih saznanja i respektovanja ključnih određenja ITSPmetodologije, kreiran je odgovarajući upitnik.

Upitnik je najpre distrubuiran zaposlenima $u$ preduzeću A, kao internim stakeholder-ima, a zatim i predstavnicima eksternih stakeholder-a, kao što su predstavnici dobavljača, tj. proizvođača, kupaca, konkurenata, finansijskih institucija i lokalne vlasti. Cilj je utvditi u kojoj meri se ispitanici slažu sa opredeljenom strategijom ulaska $u$ nove poslove $i$ pretpostavkama koje je podržavaju, i/ili alternativnom strategijom i pretpostavkama koje je podržavaju.

Empirijski rezultati dobijeni korišćenjem odgovarajućih statističkih metoda, poput metoda deskriptivne statistike, testiranja značajnosti razlika između aritmetičkih sredina i Hi kvadrat $\left(\chi^{2}\right)$ testa, predstavljaju osnovu za formiranje grupa i identifikovanje pretpostavki, kao početnih faza primene ITSP-metodologije. Vodeći računa o tome da su različite vrste stakeholder-a od ključne važnosti za kontekst datih razmatranja, može se uspostaviti veza između različitih vrsta stakeholder-a i njihovog (ne) slaganja sa predloženom strategijom ulaska u nove poslove, a $\mathrm{u}$ tu svrhu mogu se iskoristiti rezultati Hi-kvadrat $\left(\chi^{2}\right)$ test (Tabela 2). Na taj način, mogu se izdvojiti određene grupe ispitanika u odnosu na stepen slaganja sa opredeljenom strategijom ulaska $\mathrm{u}$ nove poslove (na primer, izdvojene su Grupa Za, Grupa Protiv i Grupa i Za i Protiv).

U procesu analize stakeholder-a, rezultati testiranja značajnosti razlika isto tako ukazuju na određene statistički značajne razlike između ispitanika $u$ zavisnosti od nivoa obrazovanja, vrste stakeholder-a, itd. Rezultati deskriptivne statistike ukazuju na stepen slaganja ispitanika sa opredeljenim pretpostavkama, kao i stepen važnosti i izvesnosti pretpostavki. $\mathrm{Na}$ primer, rezultati deskriptivne statistike su pokazali da se ispitanici u najvećoj meri slažu sa pretpostavkom da će rast tražnje dovesti do boljih poslovnih rezultata preduzeća $(M=4,45)$, dok se ispitanici najmanje slažu sa pretpostavkom da se ulaskom u nove poslove smanjuje rizik $(M=3,38)$. Shodno tome, može se zaključiti da je jedna od prvobitnih pretpostavki top menadžmenta istraživanog preduzeća (da se ulaskom u nove poslove smanjuje rizik) osporena, $\mathrm{tj}$. da relevatni stakeholder-i imaju drugačije mišljenje.

Najizraženija alternativna pretpostavka je da ulazak $\mathrm{u}$ nove poslove podrazumeva dodatnu edukaciju zaposlenih $(M=4,23)$. Nasuprot tome, alternativna pretpostavka sa kojim se ispitanici najmanje slažu je da su troškovi ulaska u nove poslove viši u odnosu na očekivane prinose $(\mathrm{M}=3,33)$. Dakle, dodatnu edukaciju zaposlenih ispitanici smatraju jednom od ključnih pretpostavki koje podržavaju alternativnu strategiju. Može se pretpostaviti da ovakav stav odražava rezistentnost na promene, ali može biti i posledica toga što je za organizovanje edukacija potrebno izdvojiti određena finansijska sredstva.

Identifikovane razlike su osnova za faze debate i sinteze u kojima bi trebalo da učestvuju relevantni stakeholder-i, uz istraživača, kao moderatora. S obzirom na nemogućnost istraživača da ove faze sprovede $u$ 
Tabela 2 Rezultati Hi-kvadrat $\left(\chi^{2}\right)$ testa

\begin{tabular}{ll|cccc}
\hline \multirow{2}{*}{ Stakeholder-i } & & \multicolumn{3}{|c}{ (Ne)slaganje sa predloženom strategijom } & \multirow{2}{*}{ Ukupno } \\
\hline \multirow{2}{*}{ Preduzeće A } & Ukupno & 16 & 4 & 0 & 20 \\
& $\%$ & $80,0 \%$ & $20,0 \%$ & $0,0 \%$ & $100,0 \%$ \\
Predstavnici finansijskih institucija & Ukupno & 0 & 0 & 4 & 4 \\
& $\%$ & $0,0 \%$ & $0,0 \%$ & $100,0 \%$ & $100,0 \%$ \\
Predstavnici proizvođača & Ukupno & 14 & 1 & 12 & 27 \\
& $\%$ & $51,9 \%$ & $3,7 \%$ & $44,4 \%$ & $100,0 \%$ \\
Predstavnici konkurencije & Ukupno & 8 & 2 & 0 & 10 \\
& $\%$ & $80,0 \%$ & $20,0 \%$ & $0,0 \%$ & $100,0 \%$ \\
Predstavnici kupaca & Ukupno & 8 & 3 & 2 & 13 \\
& $\%$ & $61,5 \%$ & $23,1 \%$ & $15,4 \%$ & $100,0 \%$ \\
Predstavnici lokalne vlasti & Ukupno & 1 & 2 & 0 & 3 \\
\hline \multirow{2}{*}{ Ukupno } & & $33,3 \%$ & $66,7 \%$ & $0,0 \%$ & $100,0 \%$ \\
\hline
\end{tabular}

$\chi^{2}=37,13, p=0,000$; grupa 1 - grupa Za ulazak u nove poslove; grupa 2 - grupa Protiv, grupa 3 - grupa i Za i Protiv

Izvor: Autor

realnim uslovima, izvedeni su odgovarajući zaključci o potencijalnoj debati i sintezi, respektujući date rezultate istraživanja. Naime, debata oko suprotstavljenih pretpostavki se može razvijati na različite načine. $\mathrm{Na}$ primer, pretpostavka o tome da će se ulaskom u nove poslove zadovoljiti različite potrebe kupaca i potrošača i da će to dovesti do povećanja tražnje zasnovana je na određenim informacijama sa tržišta i trendovima koji postoje $u$ datoj oblasti poslovanja. Obrazloženje date pretpostavke se ogleda $u$ tome da je kupcima i potrošačima važnija raznolikost i kvalitet ponude od cena. Ovakvo obrazloženje i pretpostavka su podržani dugogodišnjim iskustvom menadžmenta istraživanog preduzeća i postojećim trendovima $\mathrm{u}$ datoj oblasti poslovanja. Data pretpostavka se može osporiti time da u istraživanju tržišta nisu podjednako obuhvaćene sve kategorije kupaca. S obzirom da je određenim kategorijama kupaca važnija cena, može se osporiti prethodno obrazloženje. Takođe, nisu dovoljni samo iskustvo menadžmenta i postojeći trendovi, jer različite društvene i strukturalne promene zahtevaju kontinuirano praćenje i istraživanje tržišta. Na sličan način se mogu kritikovati i ostale pretpostavke.

Ipak, uprkos suprotstavljenim pretpostavkama, a vodeći računa da je sprovedeno istraživanje pokazalo da se među ispitanicima izdvaja i grupa koja podržava i strategiju ulaska $u$ nove poslove $\mathrm{i}$ alternativnu strategiju (Grupa i Za i Protiv), može se zaključiti da se sinteza između prvobitno suprotstavljenih pretpostavki može postići, što dalje znači da strategija ulaska u nove poslove, sa određenim aspektima alternativne strategije, može biti primenjena $u$ izabranom preduzeću A.

Shodno navedenom, kao podrška ITSP-metodologiji $u$ implementaciji opredeljene strategije, može se primeniti OK. Odnosno, preduzeće A se može istražiti u koncepcijskom okviru SSO modela, čime se identifikuju problemi u strukturi i funkcionisanju preduzeća. U tom smislu, u procesu identifikacije sistema, kao sistem $\mathrm{u}$ fokusu, $\mathrm{tj}$. kao operacioni elementi kojima dato preduzeće nastoji da realizuje svoju misiju, a koja se odnosi na obezbeđivanje visoko 
kvalitetnog sistema usluga vezanih za prodaju i održavanje različitih kategorija vozila, izdvojeni su sektor prodaje delova i sektor prodaje i servisiranja automobila, koji se dalje mogu dekomponovati prema različitim tipovima proizvoda (podsistemi sistema $\mathrm{u}$ fokusu). Odgovarajućim direktnim i povratnim vezama preduzeće je spregnuto sa automobilskom industrijom, koja predstavlja sistem višeg reda, tj. relevantno okruženje preduzeća.

Reč je, takođe, o preduzeću koje ima funkcionalnu organizacionu strukturu i njegovim poređenjem sa SSO modelom identifikovani su sledeći problemi: neadekvatna koordinacija između izdvojenih operacionih elemenata, odnosno funkcija koordinacije nije razvijena prema koncepciji SSO modela, centralizovana kontrola, nedovoljna razvijenost kanala revizije, neintegrisana funkcija izveštavanja, neadekvatna korporativna kultura, nedovoljna uključenost stakeholder-a u procese formulisanja ciljeva i politika, itd. Naime, identifikovani problemi pokazali su da struktura i funkcionisanje datog preduzeća znatno odstupaju od logike SSO modela.

Shodno identifikovanim problemima, može se zaključiti da je za redizajn istraživanog preduzeća od odgovarajuće važnosti da u implementaciji opredeljene svrhe i strategije respektuje određene kibernetske principe i zakone. Navedeno podrazumeva unapređenja svakog pojedinog podsistema SSO modela, tj. odgovarajućih funkcija implementacije, koordinacije, kontrole, izveštavanja i identiteta, ali i informacionih tokova i komunikacionih kanala. Generalno, redizajn istraživanog preduzeća bi trebalo da bude sproveden tako da dgovarajući operacioni elementi sami za sebe predstavljaju sisteme sposobne da opstanu sa svim meta-sistemskim funkcijama.

Dakle, identifikovanjem određenih rekurzivnih nivoa, dijagnozom funkcija predviđenih SSO modelom, kao i mogućim redizajnom preduzeća, pokazuje se kako opredeljena strategija ulaska $u$ nove poslove može efikasno biti sprovedena korišćenjem odgovarajućih kibernetskih instrumenata. Na taj način, unapređuju se kako komunikacija i kontrola, tako i adaptabilnost posmatranog preduzeća.
Osim navedenog, saznanja dobijena mogućom primenom SSO modela mogu biti ugrađena u proces formulisanja strategije. Naime, osim prezentirane moguce kombinovane primene ITSP-metodologije i OK, u kojoj je ITSP-metodologija dominantna, a OK - metodologija podrške, od odgovarajućeg značaja je istražiti kombinovanu upotrebu ITSP-a i OK, u kojoj je OK dominantna, a ITSP metodologija podrške. Zapravo, problemi dijagnostikovani primenom SSO modela mogu biti polazna osnova formulisanja odgovarajuće poslovne strategije, kao odgovor na identifikovane probleme.

\section{KRITIČKI OSVRT}

Istraživanjem različitih percepcija, interesa, vrednosnih sistema, ciljeva relevantnih stakeholder-a posredstvom ITSP-a omogućava se efektivno bavljenje pluralističkim aspektima istraživane problemske situacije, tj. dimenzijom odnosa učesnika. Nasuprot tome, $\mathrm{OK}$, kroz SSO model, doprinosi izgradnji efikasne i adaptabilne organizacije, koja će implementirati prethodno usaglašene ciljeve i strategije relevantnih stakeholder-a, tj. omogućava efikasnije bavljenje dimenzijom sistema. Identifikovane ključne manjkavosti ITSP-metodologije i OK će time biti prevaziđene. Takođe, kombinovanjem ITSP-metodologije i OK se može prevazići i to što se ITSP fokusira na sam proces rešavanja problema i donošenja odluka, pri čemu se ne preciziraju načini i ishodi implementiranja preliminarno identifikovanih alternativa, kao ni rešenja koje rezultira iz procesa dijalektičke sinteze. Zapravo, OK će omogućiti izgradnju organizacione strukture kojom će se realizovati prethodno opredeljena rešenja. Zatim, zamerke upućene SSO modelu koje se odnose na to da omogućava samo traganje za alternativnim načinima dostizanja prethodno opredeljenih ciljeva, mogu biti otklonjene njegovom kombinovanom upotrebom sa ITSP-metodologijom.

Međutim, neke manjkavosti ITSP-metodologije i OK neće biti otklonjene njihovim kombinovanjem. Reč je o sledećim ograničenjima, pre svega, ITSPmetodologije koja neće biti otklonjena upotrebom OK, kao metodologije podrške: u mnogim situacijama ne mogu se jasno identifikovati uzroci i podsticaji za 
sprovođenje dijalektičkog procesa rešavanja problema tj. strukturiranja problemskih situacija, kao ni izvori alternativnih, oprečnih rešenja problema; ne postoje jasne smernice na koji način doći do sinteze, a nije izvesno ni da će čitav proces rezultirati sintezom.

Takođe, ITSP i OK poseduju određene zajedničke nedostatke, koji se odnose na to da ni ITSP, ni OK neće dati dobre rezultate $u$ prisilnim problemskim situacijama. Naime, smatra se da će primena dotičnih prilaza, pre svega, biti u interesu onih koji poseduju moć, budući da se ove dve metodologije ne bave pitanjima moći, načinima na koji je ona distribuirana kroz neku organizaciju, i slično. Shodno tome, teško je obezbediti izvornu, autentičnu participaciju svih relevantnih stakeholder-a i neka pitanja nikad i ne budu postavljena i istražena. Zapravo, pitanje realne uključenosti stakeholder-a i njihove posvećenosti implementaciji utvrđene strategije neće biti adekvatno tretirano kombinovanom upotrebom ITSP-a i OK. Na taj način, potvrđuje se da ni ITSP-metodologija, iako identifikuje skrivene pretpostavke koje utemeljuju neku strategiju, kao ni OK ne mogu da pomognu u otkrivanju različitih odnosa snaga i moći koji postoje u nekom preduzeću. Odnosno, mogu da postanu sredstvo koje podupire interese onih koji poseduju moć $u$ nekoj organizaciji. Navedeno ograničenje kombinovanja ITSP-a i OK koje se tiče prisilnih problemskih situacija bi moglo da se otkloni uključivanjem nekih od emancipatornih sistemskih prilaza, poput Metodologije sinergijski integrisanog tima ili Kritičke heuristike sistema.

Osim navedenih, za kombinovanu upotrebu ITSPmetodologije i OK, relevantna su i određena filozofska, kognitivna, kulturalna i praktična ograničenja kombinovnog korišćenja sistemskih metodologija (Mingers \& Brocklesby, 1997; Mingers 2001; Kotiadis \& Mingers, 2006). Budući da je reč o kombinovanju metodologija iz hard i soft paradigme, posebno je izražen problem paradigmatske nesamerljivosti, po kojoj: "Grupe naučnika, oslonjene na različite paradigme, kada gledaju iz iste tačke i $\mathrm{u}$ istom smeru, vide različite stvari“" (Kuhn, 1962, prema Petrović, 2004, 164). Zatim, nedostatak kompetentnosti u korišćenju oba prilaza predstavlja važno kulturalno ograničenje. Različiti tipovi ličnosti imaće različite sklonosti ka korišćenju određenih prilaza, a postojaće i određene teškoće $u$ prelasku sa jedne na drugu paradigmu, što može predstavljati kognitivne barijere kombinovne upotrebe datih prilaza. Konačno, mogu se navesti sledeća praktična ograničenja: kombinovana upotreba ITSP- a i OK zahteva više vremena; karakteristike uočenog problema ukazuju na veću efektivnost individualne upotrebe ovih metodologija; nedostatak iskustva; sklonost ka konzervativizmu, i slično.

\section{ZAKLJUČAK}

Vodeći računa o identifikovanim ograničenjima ITSPmetodologije i OK, u radu je opredeljen i ilustrovan mogući način integrisane primene navedenih sistemskih prilaza, koji podrazumeva kompletnu primenu ITSP-metodologije $\mathrm{u}$ podsistemu $\mathrm{S}_{5}$ SSO modela, zaduženog za opredeljivanje identiteta organizacije. Pošto je prva faza primene SSO modela identifikacija sistema, tj. identifikovanje ciljeva koje treba slediti, primenom ITSP-metodologije $\mathrm{u}$ podsistemu $\mathrm{S}_{5}$ se obezbeđuje identifikovanje i usklađivanje različitih shvatanja relevantnih stakeholder-a. Dalja dijagnoza preduzeća tj. organizacije u koncepcijskom okviru SSO modela omogućava identifikovanje problema u strukturi i funckionisanju. Može se zaključiti da se sinergijskom primenom ITSPmetodologije i OK otklanjaju određena ograničenja njihove individualne upotrebe. Ipak, neke manjkavosti (poput upravljanja prisilnim problemskim situacijama, kao i neka filozofska, kulturalna, kognitivna i praktična ograničenja) ne mogu biti otklonjene.

Uprkos navedenim ograničenjima, u radu su pokazane određene mogućnosti i snage kombinovanja datih sistemskih metodologija u upravljanju problemskim situacijama $u$ preduzećima. Zapravo, doprinos prezentiranog istraživanja se ogleda $u$ istraživanju važnih pitanja u savremenom Systems Science-u, koja se odnose na kombinovanje sistemskih metodologija iz različitih paradigmi. Kao autentičan doprinos, može se istaći identifikovanje metodološki primerenog sinergijskog korišćenja, tj. kombinovanja ITSP-metodologije i OK, kojim može biti kreativno unapređen proces upravljanja problemskim situacijama u preduzećima. 
Naime, sprovedeno istraživanje je omogućilo, pre svega, identifikovanje problemskih situacija u preduzećima u kojima se bolji rezultati postižu kombinovanjem ITSPmetodologije i OK, nego njihovom individualnom upotrebom. U metodološkom smislu, implikacije sprovedenog istraživanja se odnose na određen redosled primene odgovarajućih instrumenata, tj. metoda navedenih metodologija $u$ upravljanju problemskim situacijama u preduzećima. Praktične implikacije prezentiranog istraživanja se ogledaju u identifikovanju načina na koje instrumenti navedenih sistemskih metodologija mogu pomoći menadžerima $\mathrm{u}$ celovitom razumevanju i unapređivanju procesa upravljanja problemskim situacijama u savremenim preduzećima. Dakle, sveukupna prezentirana razmatranja upućuju na zaključak da je ključna hipoteza u radu potvrđena.

Od odgovarajućeg značaja je ukazati na sledeća ograničenja sprovedenog istraživanja. Pre svega, u radu je razmatran jedan od mogućih načina kombinovanja ITSP-metodologije i OK u kome primena ITSP-metodologije prethodi primeni OK. Shodno tome, kombinovana upotreba ITSPmetodologije i OK, u kojoj je OK dominantna, a ITSP metodologija podrške predstavlja relevantno područje budućih istraživanja. Isto tako, u radu nisu istražene mogućnosti kombinovanja ITSP i OK sa određenim emancipatornim sistemskim prilazima, poput Kritičke heuristike sistema i Metodologije sinergijski integrisanog tima. Dakle, u kontekstu navedenih ograničenja, od posebnog značaja za buduća istraživanja je njihova sinergijska upotreba sa nekom emancipatornom sistemskom metodologijom, kako bi se na adekvatan način u istraživanje uključila i pitanja povezana sa odnosima moći i prisile u savremenim preduzećima.

\section{REFERENCE}

Ashby, W. R. (1966). An Introduction to Cybernetics. New York, NY: John Wiley and Sons, Inc.

Azadeh, A., Darivandi, K., \& Fathi, E. (2012). Diagnosing, Simulating and Improving Business Process Using Cybernetic Laws and the Viable System Model: The Case of a Purchasing Process. Systems Research and Behavioral Science,
29(1), 66-86. doi: 10.1002/sres.1102

Beer, S. (1994a). Brain of the Firm. Chichester, UK: John Wiley and Sons.

Beer, S. (1994b). Diagnosing the System for Organization. Chichester, UK: John Wiley and Sons.

Beer, S. (1994c). The Heart of Enterprise. Chichester, US: John Wiley and Sons.

Brocklesby, J., \& Cummings, S. (1996). Designing a Viable Organization Structure. Long Range Planing, 29(1), 49-57. doi:10.1016/0024-6301(95)00065-8

Brown, J., Cooper, C., \& Pidd, M. (2006). A taxing problem: The complementary use of hard and soft OR in the public sector. European Journal of Operational Research, 172(2), 666679. doi:10.1016/j.ejor.2004.10.016

Burell, G., \& Morgan, G. (1979). Sociological Paradigms and Organizational Analysis. London, UK: Heinemann.

Carlson, P., \& Davis, G. (1998). An investigation of media selection among directors and managers: From "self" to "other" orientation. MIS Quarterly, 22(3) 335-362. doi: $10.2307 / 249669$

Clarke, S., \& Lehaney, B. (2000). Mixing Methodologies for Information Systems Development and Strategy: A Higher Education Case Study. The Journal of the Operational Research Society, 51(5), 542-556. doi:10.1057/palgrave.jors.2600865

Elrod, R., \& Moss, S. (1998). Adversarial Decision Making: Benefits or Losses. Omega - International Journal for Managemet Science, 22(3), 283-289. doi:10.1016/0305-0483(94)90041-8

Flood, R. L. (1995). Solving Problem Solving - A Potent Force for Effective Management. Chichester, UK: John Wiley and Sons.

Habermas, J. (1972). Knowledge and Human Interests. London, UK: Heinemann.

Howerstadt, P. (2010). The Viable System Model. In M. Reynolds, \& S. Holwell (Eds.). Systems Approaches to Managing Change: A Practical Guide (pp. 191-242). London, UK: Springer.

Jackson, M. C. (1994). Critical Systems Thinking: Beyond the Fragments. System Dynamics Review, 10(2/3), 213-229. doi: 10.1002/sdr.4260100209

Jackson, M. C. (2001). Critical Systems Thinking and Practice. European Journal of Operational Research, 128(2), 233-244. doi:10.1016/S0377-2217(00)00067-9

Jackson, M. C. (2003). Systems Thinking: Creative Holism for Managers. New York, NY: John Wiley and Sons. 
Jackson, M. C. (2010). Reflections on the development and contribution of critical systems thinking and practice. Systems Research and Behavioral Science, 27(2), 133-139. doi: 10.1002/sres.1020

Kotiadis, K., \& Mingers, J. (2006). Combining PSMs with Hard OR Methods: The Philosophical and Practical Challenges. The Journal of the Operational Research Society, 57(7), 856-867. doi:10.1057/palgrave.jors.2602147

Kuhn, T. (1962). The Structure of Scientific Revolutions. The 2nd Edition. Chicago, US: The University of Chicago Press.

Markus, L. (1994). Electronic mail as the medium of managerial choice. Organization Science, 5(4), 502-527. doi: 10.1287/ orsc.5.4.502

Mason, R., \& Mitroff, I. (1981). Challenging strategic planning assumptions. New York, NY: John Wiley and Sons.

Mingers, J. (1997). Multiparadigm multimethodology. In J. Mingers, \& A. Gill (Eds.). Multimethodology: The Theory and Practice of Combining Management Science Methodologies (pp. 1-20). Chichester, UK: John Wiley \& Sons.

Mingers, J. (2001). Combining IS Research Methods: Towards a Pluralist Methodology. Information Systems Research, 12(3), 240-259.

Mingers, J., \& Broclesby, J. (1997). Multimethodology: towards a framework for mixing methodologies. Omega - International Journal for Management Science, 25(5), 489-509. doi:10.1016/ S0305-0483(97)00018-2

Mitroff, I. I., Emshoff, J. R., \& Kilmann, R. H. (1979). Assumptional analysis: a methodology for strategic problem solving. Management Science, 25(6), 583-593. doi: 10.1287/ mnsc. 24.1.44

Morgan, G. (1997). Images of Organization. London, UK: SAGE Publications.

Ngwenyama, O., \& Lee, A. (1997). Communication richness in electronic mail: Critical social theory and the contextuality of meaning. Management Information Systems Quarterly, 21(2), 145-167. doi: $10.2307 / 249417$

Ormerod, R. (1995). Putting Soft OR Methods to Work: Information Systems Strategy Development at Sainsbury's. The Journal of the Operational Research Society, 46(3), 277-293. doi: $10.2307 / 2584322$

Pérez Ríos, J. (2010). Models of organizational cybernetics for diagnosis and design. Kybernetes, 39(9/10), 1529-1550. doi: 10.1108/03684921011081150

Petrović, S. P. (2004). Sistemski prilazi rešavanju praktičnih upravljačkih problema. Ekonomski anali, 160, 147-177.

Petrović, S. P. (2010). Sistemsko mišlienje, Sistemske metodologije. Kragujevac, Republika Srbija: Ekonomski fakultet Univerziteta u Kragujevcu.

Pollalisa, Y. A., \& Dimitriou, N. K. (2008). Knowledge Management in Virtual Enterprises: A Systemic Multimethodology Towards the Strategic Use of Information. International Journal of Information Management, 28(4), 305-321. doi:10.1016/j.ijinfomgt.2008.02.005

Schwaninger, M. (2000). Managing Complexity - The Path Toward Intelligent Organization. Systemic Practice and Action Research, 13(2), 207-241. doi: 10.1023/A:1009546721353

Schwaninger, M. (2006). Intelligent Organizations - Powerful Models for Systemic Management. Berlin, Germany: Springer.

Sillince, J., \& Mouakket, S. (1997). Varieties of political process during systems development. Information Systems Research, 8(4), 368-397. doi: 10.1287/isre.8.4.368

Taylor, D., \& Tashakkori, A. (1997). Towards an understanding of teachers' desire for participation in decision making. Journal of School Leadership, 7(1), 1-20.

Trauth, E., \& O'Connor, B. (1991). A study of the interaction between information technology and society: An illustration of combined qualitative research methods. In H. E. Nissen, H. Klein, \& R. Hirscheim (Eds.). Information Systems Research: Contemporary Approaches and Emergent Traditions (131-143). North Holland, Amsterdam.

Trauth, E., \& Jessup, L. (2000). Understanding computermediated discussions: Positivist and interpretive analyses of group support system use. Management Information Systems Quarterly, 24(1), 43-79. doi: 10.2307/325097

Van der Veen, C. (2003, November). Deciding on Wicked Strategy Problem. Paper presented at the 23th SMS Annual International Conference, Baltimore, US.

Zexian, Y., \& Xuhui, Y. (2010). A Revolution in the Field of Systems Thinking - A Review of Checkland's Systems Thinking. Systems Research and Behavioral Science, 27(2), 140155. doi: 10.1002/sres.1021

Zlatanović, D. (2010). Strukturiranje upravljačkih problemskih situacija Metodologijom soft sistema. Ekonomski horizonti, 12(2), 95-112.

Zlatanović, D. (2015). Metodološki aspekti kombinovanog korišćenja sistemskih metodologija u upravljanju problemskim situacijama poslovne ekonomije. Neobjavljena doktorska disertacija, Kragujevac, Republika Srbija: Ekonomski fakultet Univerziteta u Kragujevcu. 
Primljeno 10. marta 2016, nakon dve revizije,

prihvaćeno za publikovanje 14. aprila 2016. Elektronska verzija objavljena 25. aprila 2016.

Dejana Zlatanović je docent na Ekonomskom fakultetu Univerziteta u Kragujevcu, gde je doktorirala iz uže naučne oblasti poslovna ekonomija i menadžment. Izvodi nastavu na nastavnim predmetima Ekonomska kibernetika, Nauka o menadžmentu i Kritičko upravljanje problemskim situacijama, na osnovnim i doktorskim akademskim studijama. Ključne oblasti njenog istraživačkog rada su kibernetski pristup bavljenju kompleksnim problemima u preduzećima, sistemske metodologije strukturiranja upravljačkih problemskih situacija poslovne ekonomije. 


\title{
COMBINING THE METHODOLOGIES OF STRATEGIC ASSUMPTIONS SURFACING AND TESTING AND ORGANIZATIONAL CYBERNETICS IN MANAGING PROBLEM SITUATIONS IN ENTERPRISES
}

\author{
Dejana Zlatanovic \\ Faculty of Economics, University of Kragujevac, Kragujevac, The Republic of Serbia
}

\begin{abstract}
The limitations of the individual use of systems methodologies in creative dealing with complex, dynamic and ambiguous problems, i.e. problem situations, caused by the increasing complexity and diversity of problem situations, indicate the necessity of a combined, i.e. synergistic use of systems methodologies. The aim of the research is to show how some limitations of the individual using of the interpretive systems methodology of Strategic Assumptions Surfacing and Testing (SAST) and Organizational Cybernetics (OC), as a functionalist systems methodology, can be eliminated by their combining. After identifying Critical Systems Thinking as a relevant conceptual framework for combining systems methodologies, the key features and limitations of SAST and OC are specified, and the assumptions, the conditions, the potential way, as well as the limitations of their combined, i.e. synergistic use are then determined. Despite the limitations, the methodologically appropriate combined use of these systems methodologies enables the improvement of managing problem situations in enterprises.
\end{abstract}

Keywords: managing problem situations in enterprises, the SAST methodology, the Organizational Cybernetics methodology, combining the SAST methodology and the Organizational Cybernetics methodology

JEL Classification: M10, M21 